Accepted version of paper published in Earth and Environmental Science Transactions of the Royal Society of Edinburgh, 106, 115-143.

\title{
Geology reviewed for the Falkland Islands and their offshore sedimentary basins, South Atlantic Ocean
}

\author{
Philip Stone
}

British Geological Survey, The Lyell Centre, Research Avenue South, Edinburgh EH14 4AP, UK

E-mail:psto@bgs.ac.uk

Running head:

Geology reviewed for the Falkland Islands 


\section{ABSTRACT:}

The position of the Falkland Islands adjacent to the South American continental margin belies the close association of their geology with that of South Africa. A Mesoproterozoic basement is unconformably overlain by a Silurian to Devonian succession of fluvial to neritic and shallow marine, siliciclastic strata. This is disconformably succeeded by a largely Permian succession that near its base includes a glacigenic diamictite and thence passes upwards into a succession of deltaic and lacustrine strata. The lithological succession and the character of its deformation bear striking similarities to the Cape Fold Belt and Karoo retroarc foreland basin. Swarms of Early Jurassic dykes were coeval with the Karoo magmatism and the initial breakup of Gondwana; Early Cretaceous dykes were intruded during the opening of the South Atlantic Ocean. Offshore sedimentary basins surrounding the archipelago contain Late Jurassic to Palaeogene successions and are currently the focus of hydrocarbon exploration. Best known is the North Falklands Basin, a classic failed rift. To the SE, the passive margin, Falkland Plateau Basin may also be rift-controlled, whilst the South Falkland Basin is a foreland basin created at the boundary of the South American and Scotia plates. The role of the Falkland Islands during the breakup of Gondwana remains controversial. Compelling evidence from the onshore geology favours rotation of an independent microplate from an original position adjacent to the Eastern Cape, South Africa. Alternative interpretations, justified largely from offshore geology, favour extension of the Falkland Plateau as a fixed promontory from the South American margin.

\section{KEY WORDS:}

Cape Fold Belt, Falkland Plateau, foreland basin, Gondwana, Karoo, microplate rotation, palaeomagnetism 
The Falkland Islands lie in the SW part of the South Atlantic Ocean, centred around $52^{\circ} \mathrm{S} .60^{\circ} \mathrm{W}$., about $500 \mathrm{~km}$ east of the South American mainland. They occupy the western end of the Falkland Plateau (Fig. 1a), a rectilinear, relatively shallow water ( $<2500$ m approximately) bathymetric feature that extends eastwards from the South American continental shelf. Two large islands, East and West Falkland, are surrounded by a score of substantial subsidiary islands and hundreds of smaller islands, rocks and reefs which together comprise a total land area of just over 12000 $\mathrm{km}^{2}$. The archipelago is a British Overseas Territory but is also claimed by Argentina as Las Islas Malvinas.

\section{Figure 1 about here}

Early geological exploration of the islands was a piecemeal affair, carried out mainly by scientists attached to passing expeditions whose main focus was elsewhere. Those studies, and an assessment in the early 1920s of potential geological resources, were hampered by the lack of accurate topographical base maps which only became available in 1961. A photogeological interpretation followed (Greenway 1972), but a modern, field-based geological survey was not accomplished until the 1990s, with the map and geological report arising from that exercise (Aldiss \& Edwards 1998, 1999) providing the first comprehensive account of the onshore geology.

Offshore sedimentary basins surround the Falklands archipelago (Fig. 1b) and were intermittently investigated by reconnaissance seismic surveys from the 1950s to the 1970s. These were seen as primarily academic projects, but paved the way for more determined commercial hydrocarbon exploration from the 1980s onwards. Richards et al. (1996) provided a regional overview of the offshore basins' geology.

This review paper considers both the onshore geology of the Falkland Islands and the offshore geology of the sedimentary basins that surround them, placing the region's geological development into the context of Gondwana and its break-up. References to the geological time scale and chronostratigraphical divisions follow Gradstein et al. (2012). For the onshore area, the lithostratigraphical terminology formalised by Aldiss \& Edwards (1998, 1999) will be used throughout despite any anachronisms that arise 
from reference to older literature. As a precursor to the detailed discussion of Falklands geology, and as an introduction to the nomenclature, a summary of the geological history now follows as Section 1 of this review.

\section{An introductory geological summary}

The onshore geology is illustrated in Fig. 2 with lithostratigraphical data and the regional geological history summarised in Fig. 3. The oldest Falkland Islands rocks are the $c a 1000$ million years old, granite and gneiss of the Proterozoic Cape Meredith Complex, which has a restricted coastal outcrop on the southernmost point of West Falkland. This 'basement' complex is unconformably overlain by the West Falkland Group, a thick succession of fluvial to neritic and shallow marine, quartzite, sandstone and mudstone ranging in age from Silurian to Devonian. The outcrop of the West Falkland Group covers most of West Falkland and the northern part of East Falkland. In the southern part of East Falkland a younger succession of strata, the Lafonia Group, has near its base (the northern margin of its outcrop on Fig. 2) an Early Permian glacigenic diamictite which is followed in upward succession by a thick development of Permian, deltaic and pro-delta basinal (probably lacustrine) sandstone and mudstone. The Permian strata were deposited in a sedimentary basin formed ahead of a south-verging, fold and thrust belt that concurrently deformed the Silurian to Devonian succession before advancing into the older Permian beds. The Proterozoic complex and all of the Palaeozoic sedimentary rocks are cut by swarms of Early Jurassic or Early Cretaceous dolerite dykes.

Figures 2 \& 3 about here

With the exception of the Early Cretaceous intrusive dyke swarm, the geological development of the Falkland Islands took place in the context of the Gondwana supercontinent. Comparisons with what were then contiguous sectors of Gondwana, now preserved in South Africa, South America and Antarctica are important, and will be addressed later in this review (see especially Section 7). Correlations with South Africa have been particularly influential, with the West Falkland and Lafonia groups bearing striking similarity, respectively, to successions seen in the Cape Fold Belt and Karoo Basin. Deformational histories are also similar and the interpretation of this 
regional association is crucial to the still-controversial plate tectonic history of the Falkland Islands (see especially Section 10). Do they form part of a continental promontory fixed in relation to the South American mainland (the 'rigid' model) or are they part of a microplate that moved independently during the break-up of Gondwana (the 'rotational' model)? The latter, rotational interpretation (favoured by the author) can be traced back to the prescient proposals of Adie (1952a).

Fig. 4 shows a reconstruction of Gondwana incorporating rotation of a Falklands microplate back to a position off the SE coast of South Africa, based on illustrations in Dalziel et al. (2013) and Storey et al. (2013). It must be stressed that the underlying premise is not universally accepted but these authors, and others before them, accept $180^{\circ}$ clockwise rotation of the Falklands microplate: $150^{\circ}$ during the Late Jurassic fragmentation of Gondwana and a further $30^{\circ}$ during opening of the South Atlantic Ocean from the Early Cretaceous onwards, after the microplate's transfer to the incipient South American continental margin. This view is supported largely by evidence derived from onshore geology; the contrary 'rigid' interpretation is supported largely by evidence derived from offshore geology. The resulting geological dichotomy provides a recurring theme which will be developed and discussed as this review progresses, but at this introductory stage it is sufficient to note the general concepts and uncertainties.

Figure 4 about here

The Early Cretaceous dykes link the onshore geology with that of the offshore basins, originating through crustal extension as the South Atlantic Ocean opened following the initial break-up of Gondwana. The principal sedimentary basins around the Falklands (Fig. 1b) have recently been the subject of extensive seismic surveys and a number of exploration wells have been drilled, mostly in the North Falklands Basin. With only a few exceptions, the data collected are held on a confidential basis by the companies concerned and are commercially sensitive. Nevertheless, the general basin stratigraphy has been confirmed as a Late Jurassic and younger sedimentary succession that lays either on strata equivalent to the onshore West Falkland and Lafonia groups, or on possible Jurassic volcanic rocks (pyroclastics and/or lavas). The 
structural controls on basin formation vary considerably, as will be discussed in Section 8 of this review.

Across much of the Falkland Islands the bedrock is covered by extensive and varied Quaternary deposits. Evidence for glaciation is restricted to small cirques and associated moraine on the highest hills, but in places on the lower ground are developed spectacular periglacial blockfields (known locally as 'stone runs'). The widespread peat accumulations commonly range up to about $10 \mathrm{~m}$ in thickness. Coastal features are contradictory, with the drowned ria-type coastline replete with raised beaches and wave-cut rock terraces. The details of the Quaternary history, although offering much of interest, are beyond the scope of this review.

\section{Geological pioneers}

The first substantive geological observations in the Falkland Islands were made by Charles Darwin during two visits to Berkeley Sound, East Falkland, by HMS Beagle in 1833 and 1834. Darwin described a folded and cleaved succession of quartzite, sandstone and mudstone, from which he recovered Devonian fossils, mostly brachiopods (Darwin 1846; Morris \& Sharpe 1846). In a footnote to his 1846 paper, Darwin recorded the dolerite dyke swarm that had been discovered and reported to him by Bartholomew Sulivan in 1845 (Stone \& Rushton 2013). Fossils, again mostly brachiopods, were also acquired in 1842 during the James Clark Ross Erebus \& Terror expedition, in 1876 during the Challenger expedition (Etheridge 1885), and in 1903 during the Scottish National Antarctic (Scotia) Expedition (Newton 1906), but these added little to the overall geological appreciation. More substantial progress was made by geologists accompanying two Swedish expeditions that visited the Falkland Islands: the Swedish South Polar Expedition (1901-1903) and the Swedish Magellanic Expedition (1907-1909). Reporting after these ventures, Andersson (1907) and Halle (1911) recorded the presence on West Falkland of the 'basement' granite-gneiss complex, expanded the range of the Devonian shelly fauna, clarified the Palaeozoic stratigraphy and extended it into the Permian with the discovery of a fossil Glossopteris flora, and described a glacigenic unit (now the Fitzroy Tillite Formation) that Halle correctly correlated with the Upper Carboniferous to Lower Permian Dwyka tillites of South Africa. This regional correlation was seized upon by Wegener 
(1922, 1929) in the $3^{\text {rd }}$ and $4^{\text {th }}$ editions of his book Die Ehtstehung der Kontinente und Ozeane as evidence for his 'displacement theory' of continental drift. The association of Falklands and South African geology had been noted earlier on palaeontological grounds, and with evident surprise, by Sharpe \& Salter (1856) who were familiar with Darwin's collection, and was reiterated by Clarke (1913) in his seminal work on the Devonian 'Malvinokaffric' fauna of South America and the Falkland Islands. All of these lines of evidence were pulled together by Du Toit $(1927,1937)$ whose important influence on the continental drift debate and the associated South Atlantic correlations will be examined in more detail in Section 7.1.

Although Halle (1911) had included an outline geological map of the Falkland in his report, the first attempt at comprehensive geological mapping was by Baker (1922, 1924), the 'Government Geologist' from 1920 to 1922. Baker was principally concerned with economic geology and whilst his prospecting was unsuccessful (as was an earlier investigation carried out on behalf of the Salvesen Whaling Company (Stone \& Faithfull (2013)), his work laid the foundations for the modern interpretation of Falklands geology and he notably utilised Wegener's recently formulated ideas of continental drift to explain the geological similarities with South Africa. Baker's geological map was at a relatively small scale and was only available as a fold-out figure within his relatively obscure 1924 report. Nevertheless, for fifty years it remained the definitive representation of Falkland Islands geology until the publication by the British Antarctic Survey of a photogeological interpretation by Greenway (1972), who utilised much of Baker’s (1924) lithostratigraphy. The aerial photography utilised by Greenway had been flown in 1956 and formed the basis of the first detailed topographical maps of the islands, a series published in 1961 at a scale of 1:50 000 by the British Government's Department of Overseas Surveys.

Greenway did not visit the Falkland Islands and prior to her interpretation Baker's map and cross-section had been reproduced by Adie (1952b) and in a Spanishlanguage review by Borrello (1963) published in Argentina. Adie spent some time in the Falkland Islands and was impressed by the close similarity of the geological succession to that of his native South Africa. He developed a model of Gondwana in which the Falkland Islands originated in close proximity to the Eastern Cape (Adie 1952a). Borrello did not visit the Falkland Islands but nevertheless emphasised 
perceived geological correlations with South America from which 'Las Malvinas' were, he deduced, a continental promontory. A regional review by Mitchell-Thomé (1970) also reproduced Baker's geological map and cross-sections and gave equal weight to the seemingly incompatible regional correlations of Adie (with South Africa) and Borrello (with South America) whilst lamenting the lack of comprehensive field data.

Offshore, seismic refraction profiles had been shot across the Falklands area in the late 1950s as part of an academic research project based at the Lamont-Doherty Geological Observatory (now Earth Observatory) of Columbia University in the City of New York, USA. These were followed by more seismic research studies focussed not on hydrocarbon potential but on the fundamental nature of the Falkland Plateau. This phase of activity culminated in 1974 in the drilling of three boreholes on the Maurice Ewing Bank, some $600 \mathrm{~km}$ to the east of the Falkland Islands (Fig. 1), during Leg 36 of the international Deep Sea Drilling Project. One of the boreholes (DSDP 330) proved a basement of crystalline metamorphic rocks (Tarney 1977) similar to some of the lithologies seen in the Cape Meredith Complex (but also with some significant differences); also proved was the existence of a potential oil source rock. The latter discovery encouraged more commercial interest and during the 1977-78 austral summer two speculative, regional seismic surveys were shot around the Falkland Islands. Data from these surveys remained proprietary and were not made publically available.

\section{Political complications and economic development}

Despite the obstacles to cooperation introduced by the long-standing Argentine territorial claim to Las Malvinas, relations were sufficiently amicable between 1970 and 1980 for several Argentinean geologists to work in the Falkland Islands, concentrating on local specialist issues rather than regional survey. Their contributions have been summarised by Aldiss and Edwards (1999, p. 5). This involvement came to an abrupt end in 1982, but as Argentina has vigorously reasserted the claim a parallel topographical nomenclature has been created (and continues to grow). Inevitably, the alternative gazetteer (Permanent Committee on Geographical Names 2006) has influenced the lithostratigraphical terminology 
applied, albeit inconsistently, in the Argentine literature (e.g. Turner 1980, Limarino et al. 1999, Mendía et al. 2008). In the Malvinas archipelago the two main islands become Gran Malvina (West Falkland) and Isla Soledad (East Falkland) and these names are applied to the West Falkland and Lafonia groups respectively; the Cape Meredith Complex is usually renamed Complejo Cabo Belgrano. With Lafonia released, that name then sometimes displaces Fitzroy in a Lafonia (or Lafonian) Tillite Formation, though the tillite (diamictite) does not crop out in Lafonia sensu stricto. During the brief Argentine military occupation of the islands in 1982, the town of Stanley (founded in 1843) was renamed Puerto Argentino. The usage has been maintained in Argentine literature and accordingly the Port Stanley Formation is commonly (though not invariably) disavowed, Formación Caleta Shag (from Shag Cove, a location in Gran Malvina) being preferred, after Scasso \& Mendía (1985). In defining their terminology, Scasso \& Mendía pointed out the inappropriateness of Formación Monte María that had been introduced by Borrello (1963) to incorporate both the Port Stanley and Port Philomel formations, but which was erroneously named after an area that subsequently proved to be part of the Port Stephens Formation outcrop (Aldiss \& Edwards 1999, 27 and 29). The inevitable confusion arising from these and many other alternative usages seems likely to continue.

At the larger, plate tectonic scale there is also an alternative terminology. In many modern interpretations the Falkland Islands continental area is regarded as a separate Falklands microplate (see especially Sections 7 and 10, below) but Ben-Avraham et al. (1993) referred to the same concept as the Lafonia microplate. Some authors have maintained this usage, e.g. Dalziel et al. (2013), perhaps as a way of avoiding the Falklands/Malvinas sensitivities. That may not help. Lafonia was named after Samuel Fisher Lafone, an English businessman based in Montevideo (Uruguay) who acquired rights to the eponymous territory in 1846 (Cawkell 2001, 75-77).

Given the state of knowledge in 1982, it seems unlikely that offshore hydrocarbons potential figured very highly in the calculations of either the Argentine or British governments when, in that year, the Falkland Islands were invaded and temporarily occupied by an Argentine military force. Thereafter, it was not until the early 1990s that renewed interest in the offshore potential led to the acquisition of more speculative seismic data to both the north and south of the archipelago. In 1996 the 
first Production Licences were awarded for acreage to the north, in the North Falklands Basin, and initiated the more focussed exploration programmes that continue today with, in 2015, the third offshore drilling campaign.

The 1990s also saw a marked increase in onshore geological activity. A comprehensive, field-based geological survey was commissioned by the Falkland Islands Government (Aldiss 1997) leading to the Aldiss \& Edwards $(1998,1999)$ map (solid geology published in two sheets at a scale of 1: 250 000) and accompanying report. At around the same time and stimulated by the offshore activity, a number of speculative consultancy group investigations and university-based academic projects were undertaken. Economic interest was not restricted to the offshore areas, and systematic onshore mineral exploration, with gold as the primary target, culminated between about 2005 and 2007 in an extensive borehole programme. Although it was economically unsuccessful, the data generated by the onshore exploration, including the results of an aeromagnetic survey, proved invaluable in terms of the broader geological interpretation.

\section{The onshore geological succession}

\subsection{Cape Meredith Complex}

The Proterozoic rocks of the Cape Meredith Complex have a narrow coastal outcrop extending for about $5 \mathrm{~km}$ around the southernmost point of West Falkland (Fig. 2). They were discovered in 1902 by the Swedish geologist J. G. Andersson who spent time in the Falkland Islands whilst waiting to rendezvous with the Antarctic, the ship supporting the 1901-1903 Swedish Antarctic Expedition. The specimens that he collected at the time were lost a year later when the Antarctic was crushed in pack-ice and sank. Andersson (1907) noted the presence of gneiss intruded by granite, and schist cut by dykes, with all lithologies and fabrics terminated abruptly at an unconformity subjacent to overlying sandstone. Baker (1924) re-examined the rocks in more detail and gave the first descriptions (and illustrations) based on microscope petrography. He noted schist cut by granite, pegmatite and lamprophyre dykes, all covered unconformably by the base of the overlying sedimentary succession (Port Stephens Formation) and described the igneous-metamorphic assemblage as the Cape 
Meredith Series. Adie (1952b) subsequently modified the name to Cape Meredith Complex in a review of Falkland Islands stratigraphy.

From their lithological character, Andersson, Baker and Adie had presumed, quite reasonably, that the Cape Meredith rocks were of Archaean age. The first radiometric dating results to be published, by Cingolani \& Varela (1976), gave Late Proterozoic ages: amphibolites of about $1100 \mathrm{Ma}$ (K-Ar); granite and gneiss of about $980 \mathrm{Ma}$ (RbSr). Cingolani \& Varela also dated lamprophyre dykes intruded into the metamorphic rocks but cut by the unconformity within the approximate range 500 to $550 \mathrm{Ma}$ (KAr). The Cape Meredith Complex had been previously sampled for dating purposes in 1969, by geologists from the British Antarctic Survey. The results (Rex \& Tanner 1982), ages of about 950 to $980 \mathrm{Ma}$ (K-Ar on biotite and hornblende from gneiss), were presented at a scientific conference in 1977 but the conference proceedings were slow to appear. Like those of Cingolani \& Varela, the Rex \& Tanner dates had relatively large errors.

A more recent assessment of the Cape Meredith Complex was provided by Thomas et al. (1997) based on detailed mapping. They defined a Big Cape Formation of interlayered amphibolite, felsic gneiss and biotite-hornblende gneiss, intruded by three generations of granitoids; a granodiorite and granite, both strongly foliated and veined by a later granite with no tectonic fabric. Age data arising from this survey were presented by Jacobs et al. (1999). From the felsic gneiss of the Big Cape Formation a U-Pb zircon age of $1118 \pm 8$ Ma was interpreted as showing the time of eruption of a rhyolitic protolith; Ar/Ar hornblende ages of $1009 \pm 14$ Ma and $1015 \pm 6$ Ma were obtained from the amphibolite. The three phases of granitoid intrusion spanned an age range of about 1090 to $1000 \mathrm{Ma}$. The overall interpretation was of Mesoproterozoic generation of the Cape Meredith Complex, with relatively rapid cooling thereafter, and no evidence of any subsequent thermal overprinting.

A range of dykes cut the metamorphic and plutonic components of the Cape Meredith Complex, as noted by the early investigators, and these were described in detail by Thistlewood et al. (1997). Four dyke groups were identified, the first three of which were intruded prior to uplift, erosion and deposition of the unconformably overlying sedimentary succession. The relative ages of the two oldest dyke groups have been 
disputed (Thomas et al. 1998) but as described by Thistlewood et al., the earliest dykes are diverse lamprophyres (spessartite, minette and vogesite) showing varying degrees of alteration. The most reliable age obtained, $523 \pm 9 \mathrm{Ma}$ (K-Ar, biotite from vogesite) is within the range reported from the same dyke suite (and probably the same dyke) by Cingolani \& Varela (1976). Two younger, but still pre-unconformity, dyke groups were of differing doleritic compositions and gave poorly defined Ordovician and Silurian ages respectively. The Silurian age of $422 \pm 39$ Ma provided a broad constraint on the maximum age of the unconformably overlying sedimentary strata. The fourth of the dyke groups defined by Thistlewood et al. (1997) comprised dolerites that cut across the unconformity and were members of the Early Jurassic swarm seen widely in adjacent parts of West Falkland. The Mesozoic dyke swarms will be considered later in this review in Section 6 .

\subsection{West Falkland Group}

The older of the two Falkland Islands sedimentary successions was originally assigned the informal names Devono-Carboniferous Series (Baker 1924) or the Devono-Carboniferous Group (Greenway 1972). Borrello (1963) had introduced the term Sistema de Gran Malvina which transformed, via the Argentine literature, into the Gran Malvina Group of Marshall (1994a) and finally, using the name for the same geographical area that is preferred by its inhabitants, the West Falkland Group of Aldiss \& Edwards (1998, 1999). There are four component formations (Figs 2 and 3).

\subsubsection{Port Stephens Formation}

Forming the lowermost division of the West Falkland Group, the Port Stephens Formation comprises as much as $4500 \mathrm{~m}$ of quartzitic and quartzo-feldspathic sandstone in East Falkland (where the base is not seen), but only about $2500 \mathrm{~m}$ are present in West Falkland. Some of the sandstone is coarse-grained and grades up to granule to pebble conglomerate with, in West Falkland, a thin basal unit of red mudstone overlying the Cape Meredith Complex. Coarse-grained sandstone dominates the middle part of the succession, with fine-grained sandstone more abundant in the upper and lower parts; cross-bedding and bioturbation is widespread. Detailed descriptions have been provided by Aldiss \& Edwards (1999) and Hunter \& 
Lomas (2003) who define, respectively, either six or five members, the difference caused by the appearance of an additional (fine-grained) basal member in East Falkland. The Formation has an extensive outcrop in West Falkland and the northern half of East Falkland (Fig. 2).

The depositional environment was fluvial to neritic and shallow marine. The detailed study by Hunter \& Lomas (2003) identified a range of lithofacies and ichnofaunal assemblages that together indicated terrestrial and shallow-marine deposition on an extensive, gently shelving alluvial to coastal plain, deepening to the present-day NE; palaeocurrent flow was also predominantly towards the NE. Regional subsidence was gentle and long-lived, with sediment (including abundant well-rounded grains reminiscent of aeolian deposits) supplied from a mature, continental source. Nevertheless, differences in the heavy mineral content of sandstones from the different members suggest that there was some provenance variation (Aldiss \& Edwards 1999). The vertical variation in lithofacies was thought to arise from a transgressive - regressive - transgressive palaeoenvironmental pattern, with most of the sediment accumulating during the regressive phase.

Apart from the extensive array of trace fossils the Port Stephens Formation is unfossiliferous in terms of macrofauna but Lochkovian (earliest Devonian) spores have been recovered form the upper part of the formation (Marshall in press). The depositional age of the lower part of the formation is most likely to be Silurian, with the maximum age poorly constrained by the probably Silurian date (422 $\pm 39 \mathrm{Ma}$ ) obtained from a pre-unconformity dyke in the underlying Cape Meredith Complex. The minimum age is constrained by the Early Devonian (Pragian to Emsian) age of fossils from the overlying Fox Bay Formation.

One remote inlier of likely Port Stephens Formation strata must also be noted and its presence requires some explanation. About $50 \mathrm{~km}$ south of the southernmost point on East Falkland, the small and isolated Beauchêne Island is most probably composed of Port Stephens Formation quartzite and quartz-sandstone (Edwards 1997). The occurrence lies within the southernmost West Falkland Group outcrop shown in Fig. $1 b$, to the south of the younger strata in the Lafonia Group outcrop and to the north of the Mesozoic, South Falkland Basin. Its elevation may be the result of regional 
tectonics associated with the S-verging Falklands fold and thrust belt, to be discussed further in Section 5.2. Alternatively, as will be discussed in Section 8.2, uplift may have been driven by tectonic processes further south. There, the South Falkland Basin is a north-verging foreland basin formed at the sinistral transpressive boundary between the South American and Scotia plates. The uplift of the West Falkland Group to create the Beauchêne Island inlier could be part of the forebulge development associated with that basin.

\subsubsection{Fox Bay and Port Philomel formations}

Conformably overlying the Port Stephens Formation, although with a probably transgressive base, is a succession of yellow-brown, fine- to medium-grained subarkosic and micaceous sandstone, siltstone and mudstone which together comprise the Fox Bay Formation. Its outcrop coincides with much of the lower-lying ground in West Falkland and the northern half of East Falkland (Fig. 2). The Formation is about $650 \mathrm{~m}$ thick in the south of West Falkland, but this figure increases to the north and east to a maximum of approximately $1500 \mathrm{~m}$ in parts of East Falkland. Detailed descriptions were given by Marshall (1994a) and by Aldiss \& Edwards (1999) who separated a local member at the top of the succession in parts of West Falkland. Bioturbation is widespread and a varied shelly fauna is locally abundant.

A shallow marine depositional environment is likely for most of the succession, ranging from inner shelf to shoreface. Widespread hummocky-cross-stratification demonstrates deposition within the reach of storm wave-base, whilst plane- and crossbedded sandstones suggest relatively high-energy transport and deposition, perhaps with a tidal influence. Lithofacies distribution indicates a deepening of the depositional environment towards the north and east, but superimposed on this is a series of at least four shallowing-upwards sedimentary cycles defined by the proportion of sandstone to mudstone, more of the latter being characteristic of the deeper-water accumulations. Some mudstone beds carry carbonate-rich and/or pyritic concretions, usually nucleated on fossil material.

The 'Malvinokaffric' fossil fauna from the Fox Bay Formation is well-known and is generally regarded as Emsian (Early Devonian) in age, although palynomorph 
assemblages show that the overall age range of the formation is late Pragian to early Eifelian (Marshall in press). A characteristic population of brachiopods and trilobites (calmoniids and homalonotids) is commonly accompanied by bivalves, crinoids and gastropods, and more rarely by orthocones, conularia, bryozoa and tentaculitids. Descriptions have been published of several collections acquired by passing expeditions in the $19^{\text {th }}$ and early $20^{\text {th }}$ centuries (see Section 2 and Stone \& Rushton 2012), but the outstanding contribution from that period was by Clarke (1913). Further additions were made by Baker (1924). Clarke's calmoniid trilobite material was reassessed by Edgecombe (1994), and the recent faunal list compiled by Aldiss \& Edwards (1999), based on modern taxonomy, comprised 39 taxa including 12 brachiopods, 6 trilobites and 11 bivalves. This total has been subsequently extended by the discovery of additional trilobite species (Carvalho 2006) and rare acanthodian fish spines (Maisey et al. 2002) during a collecting expedition to the islands from the American Museum of Natural History in 2000, and a starfish-like ophiuroid (Rushton \& Stone 2011; Hunter et al. in review). Examples of the Fox Bay Formation fauna are shown in Fig. 5.

\section{Figure 5 about here}

The top of the Fox Bay Formation is transitional into the overlying Port Philomel Formation, a division recognised by Baker (1924) and by Aldiss \& Edwards (1998, 1999) but which is sometimes included within the Fox Bay Formation (e.g. Marshall 1994a) since the respective lithologies are broadly similar: soft, yellow-brown sandstone with associated siltstone and mudstone. The Port Philomel Formation as defined by Aldiss \& Edwards thickens eastwards from approximately 150 to $350 \mathrm{~m}$. It contains a higher proportion of medium-grained sandstone, disposed in a wider range of bed-forms - planar- and flaser-lamination, trough-, wedge- and tabular-crossbedding, climbing ripples, channel-fill features and fining-upwards cycles - than is seen in the underlying Fox Bay Formation. But the most characteristic traits, although not strictly lithostratigraphic, are the widespread presence of fossil lycopsoid plant material and the absence of a marine shelly fauna. A broadly deltaic depositional environment seems most likely. 
Some of the plant fossils collected by Halle and Baker from what would now be regarded as the Port Philomel Formation were described by Seward \& Walton (1923) as being most probably of Mid Devonian age. This was confirmed when another of Halle's specimens that was subsequently re-examined proved to contain Givetian palynomorphs in addition to the plant macrofossils (Cramer \& Cramer 1972). Subsequent palynological work by Marshall (in press) demonstrated the presence of early Givetian assemblages. Very rare and fragmentary fish (placoderm) remains have also been reported (Maisey et al. 2002).

\subsubsection{Port Stanley Formation}

The highest division of the West Falkland Group, the Port Stanley Formation, is characterised by hard, pale grey quartzite and medium-grained quartz-rich sandstone interbedded with siltstone and mudstone. Most noticeably in West Falkland, the base is locally erosive into the underlying Port Philomel Formation, but this is not thought to represent a significant time gap. The Port Stanley Formation is about $500 \mathrm{~m}$ thick in West Falkland, where the outcrop forms the high ground adjacent to the north and east coasts, but thickens eastward to about $1100 \mathrm{~m}$ in East Falkland. There the outcrop forms the E-W zone of high ground in the centre of the island, the Wickham Heights and its eastward extension towards Stanley (Fig. 6a). At the western end of the Wickham Heights lies Mt Usborne (705 m), the highest point in East Falkland (Fig. 6b), whilst the Port Stanley Formation also forms the highest point in West Falkland, Mt Adam (700 m), in the NW part of that island (Fig. 2). A detailed description is provided by Aldiss \& Edwards (1999), although the Port Stanley Formation remains less well-documented than the lower part of the West Falkland Group.

\section{Figure 6 about here}

Quartz-rich, coarse to medium-grained sandstone and quartzite are the most commonly exposed lithologies (Fig. 7a), but that probably gives a false impression of their proportion in the formation as a whole. Interbeds of siltstone and mudstone are common, and some of the mudstones are highly carbonaceous. Many of the sandstone beds show large-scale planar or tabular cross-bedding (Fig. 7b), which is slumped or overturned in places, whilst other beds are thick, exceptionally up to $3 \mathrm{~m}$, and plane- 
bedded; some contain a scattering of small mud flakes. The depositional environment was most probably a marine shoreface with tidal channels, although Meadows (1999) regarded the Port Stanley Formation as accumulating in a probably braided, fluvial channel system.

\section{Figure 7 about here}

Lycopsoid plant stem impressions and carbonaceous leaf traces are locally present, particularly in the lower part of the Port Stanley Formation, but no faunal macrofossils have been reported and even trace fossils are extremely rare. Palynology studies by Marshall (1994, in press) determined a Famennian (Late Devonian) age near the top of the formation, whilst a maximum age is defined by the Givetian age of the underlying Port Philomel Formation.

\subsection{Lafonia Group}

Halle (1911) described the younger of the two Falkland Islands sedimentary successions as the Lafonian Series, which was then divided by Baker (1924) into an Upper and a Lower Lafonian Series. These names were carried forward by Greenway (1972) as upper and lower groups within a Lafonian Supergroup, but meanwhile Borrello (1963) had changed the name to Sistema de la Isla Soledad; Borrello’s terminology became the Grupo Isla Soleded in subsequent Argentine literature. Aldiss \& Edwards $(1998,1999)$ re-established Halle’s original concept as the Lafonia Group, with five component formations (Fig. 3). Detailed descriptions have been provided by Aldiss \& Edwards (1999) and Trewin et al. (2002).

\subsubsection{Bluff Cove, Fitzroy Tillite and Port Sussex formations}

These three formations are equivalent to the Lower Lafonian Series of Baker (1924) and the Lower Lafonian Group of Greenway (1972). The lowest of the three, the Bluff Cove Formation, occurs only in East Falkland where it disconformably overlies the Port Stanley Formation. It comprises about 200 m of mostly fine-grained, quartzo-feldspathic sandstone containing white mica, laminated siltstone and mudstone, locally affected by soft-sediment deformation. Adie (1952b) and Dawson 
(1967) regarded the strata as proglacial deposits, either glacimarine or glacilacustrine, and reported dropstones in the upper part of the formation which increased in number upwards to merge with the overlying Fitzroy Tillite Formation. In their formal definition of the Bluff Cove Formation, Aldiss \& Edwards (1999) thought that the dropstone-bearing beds were more appropriately included in the overlying Tillite Formation.

No macrofossils have been recovered from the Bluff Cove Formation, and both bioturbation and trace fossils are rare. The age would seem to be constrained by scarce spores and pollen from a mudstone, reported by Aldiss \& Edwards (1999) as being 'Late Carboniferous or younger'; conversely, Meadows (1999) reported the presence of Devonian palynomorphs. A Carboniferous (or Early Permian) age would be more compatible with the regional associations so perhaps the Devonian material was derived and recycled from the underlying West Falkland Group. In dating the onset of glaciation it is also worth noting the diamictite-filled sedimentary dykes cutting down into Port Stephens Formation strata that were reported from West Falkland by Hyam et al. (1997) and which contain mid-Carboniferous (Late Visean to Early Namurian) palynomorphs. If these sedimentary dykes were formed during a widespread mid-Carboniferous glacial episode, as seems likely, any other resulting deposits were removed by the subsequent Early Permian glaciation that deposited the Fitzroy Tillite Formation (described below).

In East Falkland the Bluff Cove Formation appears to be conformably succeeded by the glacigenic diamictite of the Fitzroy Tillite Formation. In West Falkland the diamictite rests unconformably on Port Stanley Formation strata with an angular discordance of up to $20^{\circ}$ (Frakes \& Crowell 1967). The thickness of the deposit decreases westwards across East Falkland from about $900 \mathrm{~m}$ to $750 \mathrm{~m}$; about $650 \mathrm{~m}$ is present on the east coast of West Falkland but farther west the thickness may increase to about 850 m (Aldiss \& Edwards 1999). The nature of the deposit was first recognised by Halle (1911), more information was provided by Baker (1924) and an in-depth study was made by Frakes \& Crowell (1967). These authors, and several others subsequently, used 'Lafonian' as the geographical descriptor of a tillite/diamictite lithostratigraphical division, but as pointed out by Aldiss \& Edwards 
(1999) the unit has no outcrop in that part of East Falkland known as Lafonia (Fig. 2). Accordingly, Aldiss \& Edwards defined their equivalent Fitzroy Tillite Formation.

The East Falkland outcrops are of a massive or weakly thick-bedded, sandy diamictite containing a variety of matrix-supported erratic clasts, most commonly of quartzite or granitic lithologies. A slightly different lithofacies is seen in West Falkland where, in the west, the diamictite is more friable, contains a greater range of clasts in terms of both size and composition (Fig. 7c), and locally contains linear sandstone bodies. A sporadically-developed, sub-horizontal fabric (Fig. 7d) is probably a relict of an original stratification, modified by sub-glacial deformation. On the east coast of West Falkland, a 5-6 m thickness of laminated sandstone and siltstone with sporadic dropstones, was noted by Frakes \& Crowell (1967) to be interbedded within the massive diamictite; they ascribed patchy reddening to contemporary subaerial weathering. This laminated unit was subsequently separated as a distinct member by Aldiss \& Edwards (1999), who concluded that it was of Sakmarian age, and by Meadows (1999)

All those who have investigated the diamictite have noted that the range of clasts lithologies includes many that can be related to local sources within the Cape Meredith Complex or the West Falkland Group, but also includes a proportion of entirely exotic lithologies: e.g. garnet-gneiss, various porphyritic igneous rocks, quartz-pebble conglomerate and limestone. A recent discovery of fossiliferous limestone containing an Early Cambrian archaeocyath-trilobite fauna (Figs 5f \& 7d) (Stone \& Thomson 2005; Stone et al. 2012) has significance for regional correlation and palaeogeography and will be returned to in Section 7, below.

Frakes \& Crowell (1967) distinguished three diamictite lithofacies related to different depositional environments. In the west, they proposed a grounded ice-sheet with the deposits incorporating the linear sand bodies thought to have originated as eskers. Farther east in West Falkland, a more disturbed lithofacies was related to slumping and remobilisation on a submarine slope, whilst the massive diamictite of East Falkland was regarded as a glacimarine deposit. The glacimarine aspect was disputed by Aldiss \& Edwards (1999) who considered the features shown to be more characteristic of subglacial till deposited directly from the base of an ice sheet. They 
noted in particular the absence of dewatering structures and the random orientation of clast axes. A similar conclusion was reached by Horan (2015) after a detailed study of the diamictite made possible by the recovery of borehole core generated between 2005 and 2007 during a mineral exploration project (Stone 2011; Stone \& Horan in press). Horan reiterated the absence of any signs of reworking by water movement, provided more detail on the random orientation of clasts, and noted local glacitectonic structures. The latter included brecciation and fissility, planar shearing and rotational deformation fabrics around clasts.

The regional association of the Fitzroy Tillite Formation with other deposits of the Carboniferous to Permian glaciation of southern Gondwana has been long-recognised (e.g. Halle 1911, Baker 1924). By comparison with the correlative Dwyka Group tillites of South Africa (more on this in Section 7, below) Aldiss \& Edwards (1999) concluded that deposition of the Fitzroy Tillite was largely Early Permian in age, mostly Asselian and Sakmarian but possibly continuing into the Artinskian, i.e about 290-300 Ma. This age range was broadly supported by U/Pb dating of juvenile zircons from tuff layers within Dwyka Group mudstones in southern Africa (Bangert et al. 1999).

Given the overwhelming evidence for a glacigenic origin, the recent proposal by Rocca \& Presser (2015) that all or some of the Fitzroy Tillite Formation might be a meteorite impact breccia seems a little fanciful. The site of the putative massive impact was taken to be a large gravity anomaly to the west of the Falkland Islands, shown on Fig. 1 as an offshore, largely Permian basin following the interpretation of Richards et al. (1996).

Stratigraphically above the Fitzroy Tillite is a variable succession of three distinctive units that are defined as members of the Port Sussex Formation. Although each member contains a high proportion of dark grey or black mudstone, their contrasting lithofacies and depositional palaeoenvironment, and regional importance for correlation (see Section 7, below) make their individual description and assessment a useful departure. In upward succession and as defined by Aldiss \& Edwards (1999), the Port Sussex Formation comprises the Hells Kitchen, Black Rock and Shepherds 
Brook members. Together they have a narrow outcrop in both East and West Falkland adjacent to the top of the Fitzroy Tillite Formation (Fig. 2).

The Hells Kitchen Member is a 7 to $10 \mathrm{~m}$ thickness of thinly interbedded and laminated mudstone, sandstone and diamictite with sporadic dropstones. As with the subjacent Fitzroy Tillite Formation, the fortuitous sampling of this unit during a mineral exploration drilling programme (Stone 2011) has allowed a very detailed examination and interpretation (Horan 2015; Stone \& Horan in press) showing it to be a transitional succession deposited during a fluctuating glacial regression. Horan (2015) described a complex facies interaction arising from a range of depositional processes: meltwater, release of glacial debris from ice, gravity flows, iceberg calving and current reworking. She also utilised reflectance data and high-resolution XRF logging to model cyclicity compatible with Milankovitch periodicities, so enabling a time-scale of approximately 1.2 million years to be suggested for the deglaciation transition recorded by the Hells Kitchen Member. Comparisons with the equivalent South African succession suggested that this time interval lay within the Early Permian Sakmarian Stage. A slightly younger age for the Hells Kitchen Member, within the Artinskian Stage, had been previously preferred by Aldiss \& Edwards (1999).

Horan's (2015) study of the borehole cores showed that the upward transition from the Hells Kitchen Member into the post-glacial mudstones of the Black Rock Member took place over about $2 \mathrm{~m}$. The dark grey to black mudstone may be either laminated and thinly bedded or massive, and can be either carbonaceous and pyritic or siliceous. The total organic carbon content is highly variable but reaches $40 \%$ locally (Marshall 1994a \& b; Trewin et al. 2002). Metabentonite laminae indicate contemporaneous volcanicity (Aldiss \& Edwards 1999; Trewin et al. 2002). A thickness of about $125 \mathrm{~m}$ was estimated by Frakes \& Crowell (1967); Aldiss \& Edwards (1999) thought this an overestimate for West Falkland but also considered that the East Falkland succession might be as thick as $250 \mathrm{~m}$. One problem with these figures, as noted by Trewin et al. (2002), is that the Black Rock Member is particularly susceptible to intrafolial deformation, its fissility allowing it to act locally as a décollement level. The deformation is variable but locally intense, and makes accurate thickness judgements difficult. The depositional environment was deep water and anoxic, but whether 
marine or lacustrine is uncertain. The mudstones are unfossiliferous, with only a very sparse ichnofauna reported from near the top of the succession (Aldiss \& Edwards 1999).

The Shepherds Brook Member conformably follows the Black Rock Member, and is distinguished by the interbedding of siltstone and fine-grained sandstone with the mudstone, the sandstone introduced by density currents. Thin metabentonite layers occur towards the top of the succession, which is about 150 m thick in East Falkland, probably a little less in West Falkland (Aldiss \& Edwards 1999, Trewin et al 2002). Two occurrences of plant material have been reported, and a few trace fossils have also been noted, but the member is otherwise unfossiliferous (Aldiss \& Edwards 1999).

\subsubsection{Brenton Loch and Bay of Harbours formations}

These two formations form by far the greater part of the Lafonia Group and correspond to the Upper Lafonian Series and Group of, respectively, Baker (1924) and Greenway (1972). They were defined and described in detail by Aldiss \& Edwards (1999), with detailed interpretations also provided by Meadows (1999) and Trewin et al. (2002). There is a general correlation with the Formación Bahia Choiseul and the Formación Estrecho de San Carlos as described by Jalfin \& Bellosi (1983) and Bellosi \& Jalfin (1984).

The Brenton Loch Formation crops out mostly in East Falkland, on either side of Choiseul Sound and the Darwin isthmus, to the SW of which it forms the northern margin of Lafonia sensu stricto. There is also a very narrow, coastal outcrop of steeply-dipping beds along part of the eastern side of West Falkland, with the dip thence decreasing eastwards onto islands within Falkland Sound (Fig. 2). The formation is made up of sandstone, siltstone and mudstone (Fig. 7e) deposited either as delta-derived turbidite accumulations, or as interbedded rhythmite alternations that may have developed by seasonal influence on sediment supply (Trewin et al. 2002). The sandstones are generally feldspar-rich lithic arenites with a significant volcaniclastic component. The thickness of the formation was estimated by Aldiss \& 
Edwards (1999) to be almost $3000 \mathrm{~m}$ and was divided by them into three separate members; Trewin et al. (2002) illustrated a smaller thickness of about $1500 \mathrm{~m}$.

Plant fossils, including Glossopteris of Permian age, are widely distributed and have been described by Halle (1911) and Seward \& Walton (1923). There is also a varied and well preserved ichnofauna that includes an array of burrows and grazing trails, arthropod trackways, and several types of the remarkable fish trail Undichna, produced by fish swimming so close to the subaqueous sediment surface that their fins trailed across and left marks on the cohesive mud surface (Trewin 2000). Macrofossils are very rare, with only a single occurrence of a sparse bivalve fauna (Fig. 5g) reported from a level near the top of the formation on the south coast of Choiseul Sound (Simões et al. 2012). The bivalves (most probably of Mid Permian, Capitanian age) and ichnofauna are regarded as non-marine, suggesting a lacustrine depositional environment for the Brenton Loch Formation pro-deltaic succession. Meadows (1999) had proposed a rapidly deepening marine environment but from the evidence now available this seems less likely than the lacustrine alternative.

The outcrop of the Bay of Harbours Formation covers most of Lafonia and extends to some of the islands in Falkland Sound (Fig. 2). Sandstone, siltstone and mudstone represent delta slope and channel-fill deposits, the latter increasing in size and number towards the top of the succession with some of the larger ones showing erosive bases. Sedimentary structures show evidence of loading and de-watering, whilst crossbedding and ripple-marked bedding surfaces are fairly common (Fig. 7f). Trewin et al. (2002) describe the succession in terms of a prograding delta front, succeeded by the subaqueous muddy margin of the delta top, and then by a system of sinuous deltatop channels. A non-marine, lacustrine palaeoenvironment was preferred by those authors, and by Aldiss \& Edwards (1999), but Meadows (1999) thought the Bay of Harbours Formation to be a marine deposit laid down by submarine fans, albeit one that showed a marked shallowing trend from the environment that pertained during deposition of the Brenton Loch Formation. From the evidence now available a lacustrine setting seems the more probable.

Like those of the Brenton Loch Formation, the Bay of Harbours sandstones are generally feldspar-rich lithic arenites with a significant volcaniclastic component; 
additional evidence for contemporaneous volcanicity is provided by sporadic metabentonite layers. Aldiss \& Edwards (1999) gave the thickness of the formation as about $3000 \mathrm{~m}$, whilst Trewin et al. suggest that it could be significantly thicker than that. Two members have been described, but it is not clear that they have been envisaged in the same way by different authors. The importance of lateral lithofacies variation is difficult to define across the formation's faulted outcrop and this uncertainty may explain the difference in the thickness estimates. Bioturbation is fairly widespread, but the range of the forms present is much diminished by comparison with the Brenton Loch Formation. Fragments of petrified wood have been found at a number of locations in the Bay of Harbours Formation outcrop, and plant fossils are common, again including Glossopteris, as described by Halle (1911) and Seward \& Walton (1923). Halle also recovered, remarkably, a well-preserved insect wing, subsequently described by Tillyard (1928) as being from a damselfly.

\section{Structure}

\subsection{The historical contributions}

It was recognised by Halle (1911) that the older part of the Permian Lafonia Group had been caught up in the deformation episode that was most intensely represented in the Siluro-Devonian West Falkland Group. This deformation must therefore, he reasoned, have been of late- or post-Permian age. He described the folding on E-W axes apparent in the Wickham Heights of East Falkland as dying out to the south, and related the NNE-SSW features defining the eastern coast of West Falkland to a major fault along the line of Falkland Sound. In association with the latter, and of particular prominence, was the 'Coast Ridge' formed by the linear, coast-parallel outcrop of near-vertical beds of Port Stanley Formation quartzite (Fig. 2). The overall correlation of age and structural style between the Falkland Islands and the Cape Fold Belt in South Africa was clear to Halle but, at the time he was working, a few years prior to publication of Wegener's 'displacement theory’ of continental drift, the full importance of that association was not apparent. Instead, Halle related the Falklands structure to a 'precordilleran' zone parallel to the Andes as the extension of that mountain chain swung eastward into the Scotia Arc. In this he was influenced by the then recently published regional assessment by Suess (1909). 
Baker (1924) agreed with Halle’s interpretation for East Falkland, where the northern part was affected by folding on E-W axes, the intensity of which decreased abruptly on the south side of the Wickham Heights, whence deformation faded southwards across Lafonia. In contrast, Baker contradicted Halle’s interpretation of a major fault coincident with Falkland Sound, and correctly identified a major fold, with axis trending NNE-SSW as the principal cause of the linear Coast Ridge, although he somewhat confused the issue by, in this area, mistaking the Port Stephens Formation for the Port Stanley Formation. In regional terms, Baker espoused continental drift as the explanation for the structural correlations with the Cape Fold Belt, a correlation that will be returned to below in Section 7 .

For her photogeological interpretation Greenway (1972) was hampered by the absence of contemporary ground control. Nevertheless, she identified the E-W folding across northern East Falkland and the absence of significant deformation to the south in Lafonia. She also noted the extension of the E-W trend into the northern half of West Falkland (where it swung into a WNW-ENE orientation) but with a change of structural style: broad, open folds in West Falkland, smaller, tight, and more closely spaced folds on the limbs of larger structures in East Falkland. The dominant structure in West Falkland was confirmed as a major, strongly asymmetric anticline with an axis running NE-SW (the Hornby Mountains anticline) parallel to the adjacent linear east coast of West Falkland. The vertical beds of Port Stanley Formation quartzite that form the Coast Ridge lie within the eastern, steep limb of the near-monoclinal Hornby Mountains fold. Greenway was unable to resolve satisfactorily the relationship between the two fold trends in West Falkland, and the map accompanying her report showed that at its NE end, the Hornby Mountains anticline ran into a large-scale interference structure seemingly related to faulting along the line of Falkland Sound.

\subsection{Modern interpretations}

The modern resolution of Falkland Islands structural geology was initiated by the concurrent work of Aldiss \& Edwards (1998, 1999) and Curtis \& Hyam (1998); the following account draws on both of these sources. The first phase of deformation (D1) resulted in the folding on broadly E-W axes that had been previously identified. In 
West Falkland these were large, open structures with sub-horizontal hinges and limb dips of usually less than $10^{\circ}$ (Fig. 8, section $\mathrm{AB}$ ). There is no associated cleavage in the West Falkland mainland but farther to the north-west, in the Jason Islands, a spaced, axial planar fracture cleavage is developed in folded Port Stephens Formation sandstones. The largest island (Grand Jason) provides the best example, being formed around a large, SE-plunging, anticlinal D1 fold hinge, through which the axial planar fractures are well developed (Aldiss \& Edwards 1999, 72); minor congruous folds are also present.

Figure 8 about here

In the northern part of East Falkland, the limbs of the large first-order folds (with wavelengths of about 3-4 km) are corrugated by congruent minor folding (Fig. 9a \& b) that becomes more intense southwards into the Wickham Heights, where it is commonly tight and locally isoclinal (Fig. 8; section CD). The Port Stanley Formation strata are particularly affected, with the alternation of hard quartzite beds and fissile carbonaceous siltstone aiding minor fold development and perhaps concealing the true extent of structural displacement. A strong slaty cleavage is widely developed, mostly in the more argillaceous lithologies, and the assemblage of structures and fabric demonstrates a sense of vergence towards the south. Cleavage is most intensely developed in an E-W zone on the south side of the Wickham Heights and to the east of the Darwin isthmus. There the West Falkland Group strata and the Lafonia Group beds up to the Port Sussex Formation are all affected (Fig. 9c), but southward into Lafonia (and west of Darwin) the intensity of deformation decreases, so that the majority of the Lafonia Group strata is relatively flat-lying and has no cleavage. The overall pattern is of a S-directed fold and thrust belt culminating in a deformation front along the south side of the Wickham Heights, ahead of which is a foreland basin (Fig. 8, section CD). Within the latter, the upper part of the Lafonia Group remained undeformed (at D1 stage) with the exception of broad, gentle undulations and a number of minor, low-angle compressional thrusts, mostly directed towards the north (Fig. 9d). 
The geometry of the D1 thrust front in East Falkland is complicated by the apparent focussing of deformation within the highly fissile Black Rock Member of the Port Sussex Formation, at least locally (Fig. 9e). Given the overall regional structure, as discussed below, it would seem most probable that in places the Black Rock Member acted as a back-thrust décollement (Fig. 8, section CD). With forward-breaking thrustrelated deformation affecting the stratigraphically subjacent Fitzroy Tillite Formation immediately to the north, this would make the thrust front a structural triangle zone, albeit that the principal S-directed, forward-breaking thrusts are blind.

The second phase of deformation identified (D2) produced large-scale folding on broadly NE-SW axes, although there is much local variation around that trend. The folds are thought to be either draped over blind faults or to have formed within fault hanging walls, and occur across the western side of East Falkland and all of West Falkland. Most are relatively gentle structures, but one of more dramatic impact is the Hornby Mountains anticline that runs parallel to the east coast of West Falkland (Fig. 8, section EF). Superimposition of the D2 Hornby Mountains fold on earlier D1 structures is at least partially responsible for large-scale, fold interference patterns, the style of which suggest that the underlying D2 fault movement was reverse and dextral. Alternatively, an additional, later episode can be envisaged (D3) that involved dextral reactivation of faults in a zone spanning Falkland Sound and the adjacent coasts. The combination of D2 and D3 faulting effects has produced a particularly marked series of NE-SW structural lineaments cutting across Lafonia, some prominent components of which act as structural control on the Darwin isthmus. In tectonic terms, as described by Aldiss \& Edwards (1999), this is a narrow graben formed within the hinge zone of an open, asymmetric D2 anticline, plunging to the south-west, and with its steeper limb dipping towards Falkland Sound so as to mirror the downthrow effect of the Hornby Mountains anticline.

Aldiss \& Edwards (1999, 81-83) summarised the compelling evidence for a major fault zone coincident with the north-west side of Falkland Sound (discussed further in Section 5.2.1). However, rather than place a major fault within Falkland Sound, Hyam et al. (2000) have modelled a major, blind reverse fault beneath the Hornby Mountains anticline, across which they calculated a structural relief (down to the south-east) of 6-8 km. Geophysical data allowed the basement fault to be traced 
offshore to the SW for about $8 \mathrm{~km}$ as a series of en échelon offsets. Onshore, there is local evidence for the reactivation of the fault with minor, normal downthrow to the west. A similar substantial displacement zone occurs farther to the west, within the south-east part of the Jason Islands, but runs approximately ENE-WSW. Considerable downthrow to the south-east is indicated by the contrasts in D1 fold style and cleavage development (described above) and metamorphism (see Section 5.4).

Along the northern coastal margins of both East and West Falkland there is evidence for the late-stage renewal of S- to SW-directed thrust movement involving brittle deformation, and so likely to have occurred at a relatively high structural level. The thrust sheet (D4) consists of Port Stephens Formation strata and has been emplaced above Fox Bay Formation beds, but the relationships are locally confused by subsequent reactivation of the D4 thrust and other, earlier structures in the north of the islands as normal faults with down throw to the north. These late, extensional structures are likely to be associated with the development of the Mesozoic-Cenozoic offshore basins that surround the Falkland Islands (see Section 8 below), and although they are grouped together as D5 structures, they may have formed over an extended time interval.

The late, dominantly NW-SE extensional faulting with downthrow to the NE (D5 of Aldiss \& Edwards 1999) were thought to be more widespread and of greater significance by Lawrence et al. (1999). These investigators modelled the extensional faults as defining a series of arcuate half-grabens, the faulted (SW) side of which controlled the orientation of the northern coasts of both West and East Falkland, and which also extended south across Lafonia where the faults influenced the positions and orientations of the major embayments: Brenton Loch, Choiseul Sound, Adventure Sound, Bay of Harbours. These putative Lafonian D5 faults were not identified during the geological survey work of Aldiss \& Edwards (1998), nor were they located during subsequent field work by the author.

There is very little control on the deep structural character of the Falkland Islands; the deepest boreholes penetrated only a few hundred metres and there are no informative onshore, deep geophysical datasets. In East Falkland, a projection of the lithostratigraphical fold envelope (Fig. 8, section CD) suggests a large-scale, S- 
verging monoclinal structure, most probably driven by blind thrusting at depth. A substantial sedimentary thickness clearly underlies Lafonia, but the situation farther north is less certain. There, either crystalline basement occurs at a relatively shallow depth, or the observable structure is essentially thin-skinned above a lower duplex of West Falkland Group strata. Similar uncertainties persist in interpretations of the more extensively studied Cape Fold Belt, with a thin-skinned model incorporating duplexing and out-of-sequence and piggy-back thrusting (e.g. Hälbich 1992; Catuneanu et al. 1998) contrasting with proposals of deeper, basement fault control and strike-slip partitioning (Tankard et al. 2009).

In West Falkland, Proterozoic crystalline basement crops out in the south of the island at Cape Meredith (Fig. 8, section AB) with progressively younger divisions of the West Falkland Group appearing northwards in a relatively little-deformed succession. It is not clear whether the Cape Meredith complex basement outcrop is structurally in situ, or has been elevated by faulting within a broken foreland setting. There is evidence for S-directed thrusting in the north of West Falkland but, as in East Falkland, its deeper relationships remain unclear. Nevertheless, a shallower basement seems likely in West Falkland since, as described below, the Falkland Sound Fault and associated Hornby Mountains monocline create a substantial deep structural relief between it and East Falkland.

\subsubsection{The Falkland Sound Fault}

There is general agreement that the south-east coast of West Falkland is associated with a major fault or faults with downthrow to the east, one which is largely blind beneath the Hornby Mountains anticline (Fig. 8, section EF). Overall, downthrow was sufficient to produce a structural relief of 6-8 km between West and East Falkland (Hyam et al. 2000). The fault zone appears to have been a long-lived basement structure that was active during deposition, probably of the West Falkland Group and certainly of the Lafonia Group, with the progressive downthrow to the east allowing the accumulation of a much thicker succession in East Falkland than in West Falkland (e.g. Marshall 1994a, Aldiss \& Edwards 1999). Thereafter, continued downthrow to the east was accompanied by dextral transpressive movement, but the amount of that movement remains uncertain. At one extreme Thomas et al. (1997) argued for $300 \mathrm{~km}$ 
displacement, Hyam (1998) preferred a reduced figure of 'up to’ $60 \mathrm{~km}$, whilst Curtis \& Hyam (1998) and Aldiss \& Edwards (1999) thought the much smaller figures of, respectively, about $3.3 \mathrm{~km}$ and 5-10 km were adequate to explain the observed geological relationships. All of these authors regarded the principal dextral movements on the Hornby Mountains and/or Falkland Sound faults as being related to the D2 and D3 deformation events. Lawrence et al. (1999) noted that in the offshore area their NW-SE extensional half grabens were apparently offset along a rift transfer zone that extended the line of Falkland Sound towards the NE. Accordingly, they proposed that at least some of the lateral movement along the Falkland Sound fault system could have been a relatively late process, in effect part of the D5 deformation of Aldiss \& Edwards (1999). Evidence for localised sinistral transpresssion in East Falkland (e.g. as described by Stone (2014) at Ordnance Point, near Stanley) was thought by Hodgkinson (2002) to be a conjugate effect to the dextral movement on the Falkland Sound Fault.

\subsection{The timing of deformation}

Strata up to Early Permian in age are affected by the D1 deformation, and many authors, over many years, have commented on the correspondence in style and timing of this deformation phase in the Falkland Islands with the broadly Late Permian to Early Triassic development of the Cape Fold Belt in South Africa. The transpressive structures of D2/D3 have been related to the break-up of Gondwana and the beginnings of independent movement of a Falklands microplate. Hodgkinson (2002) reported an $\mathrm{Ar} / \mathrm{Ar}$ age of $278 \pm 8 \mathrm{Ma}$ (mid-Permian) from metamorphic white micas in a fault zone on the east coast of East Falkland that he designated a D1 structure but for which a D3 association (or at least reactivation) was preferred by Aldiss \& Edwards (1999). The initial break-up of Gondwana was associated with the intrusion of swarms of Early Jurassic dykes (see Section 6, below) and one of these, the Pebble Island dyke (Fig. 10) appears to cut the D4 thrust front in the north of West Falkland. Overall therefore, the D1 to D4 deformation episodes described from the Falkland Islands can all be regarded as broadly Permo-Triassic in age, and may represent phases within a structural continuum. The Cape Fold Belt has been described as a polyphase thrust assemblage generated sequentially between about 277 and $229 \mathrm{Ma}$ (e.g. Hälbich 1992). The D5 extensional faulting seen in the north of the islands is 
related to the offshore development of the North Falklands Basin as the South Atlantic Ocean opened (see Section 8, below) and may therefore have formed at any time from the Late Jurassic onwards. Extrapolating from their offshore interpretation, Lawrence et al. (1999) dated structures that would be associated with D5 in northern East Falkland (and also late movement on the Falkland Sound Fault) as Early Palaeogene. Late extensional fault reactivation in the Cape Fold Belt is usually considered to be a Cretaceous phenomenon (e.g. Hälbich 1992), although by that time any direct correlation with events in the Falkland Islands would have become tenuous.

Figure 10 about here

\subsection{Metamorphism}

With the exception of those forming the Proterozoic Cape Meredith Complex, all of the Falkland Islands' rocks are at a low metamorphic grade. Nevertheless, there are still significant differences between East and West Falkland. Aldiss \& Edwards (1999, figure 4.11) plotted variations in the clay mineral maturity, based on illite crystallinity, to show that almost all of the West Falkland succession, together with that forming the western and northern fringes of East Falkland, was within the Late Diagenetic Zone. Higher grades were recorded to the west and east. To the west, the outer Jason Islands lie in the Epizone; to the east, in the central part of East Falkland, grade rose to the High Anchizone with the highest grades coincident with the maximum development of cleavage within the deformation front to the south of the Wickham Heights and east of the Darwin isthmus. Most of the Lafonia Group is in the Low Anchizone, with even the youngest strata in the south of the Lafonia Group outcrop in East Falkland at a higher metamorphic grade than the oldest strata of the West Falkland Group outcrop in the south of West Falkland. Neither of these areas is much deformed and so the difference may be related to sedimentary burial, requiring a far thicker succession to have accumulated over East Falkland than West Falkland, so reinforcing the syn-sedimentary importance of a Falkland Sound fault zone, as discussed above.

A pattern of shallower sedimentary burial in West Falkland than in East Falkland was also deduced by Marshall (1994a) and Hyam et al. (2000) from vitrinite reflectance 
measurements. Marshall also described, from the northern part of West Falkland, a general northwards increase in vitrinite reflectivity from older into younger rocks, in the opposite sense to what would be expected from sedimentary burial. A corresponding northwards increase in reflectivity across the southern part of East Falkland, was related to distance from the deformation front of the main fold and thrust belt, and a similar explanation was invoked by Marshall (1994a) for West Falkland, where the deformation front lies farther to the north.

Burial, uplift and cooling histories were addressed by two studies integrating apatite fission track measurements and vitrinite reflectance: Lawrence et al. (1999) and Thomson et al. (2002). Both studies identified three discrete episodes of heating and cooling that had affected the Falkland Islands succession, albeit with some ambiguity. Their results, which were broadly compatible, were consistent with an initial cooling phase in the Late Permian or Early Triassic that was initially restricted to West Falkland. This was caused by uplift and erosion there, relative to East Falkland, coincident with the D2 deformation that initiated the Hornby Mountains anticline. Subsequent Early Jurassic cooling that affected both East and West Falkland was related by Thomson et al. to the thermal uplift preceding dyke intrusion (see Section 6, below); Lawrence et al. invoked the end of active rifting and the mid-Jurassic cessation of magmatism. Thomson et al. then identified renewed heating during the later part of the Mesozoic which they ascribed as most probably the result of subsidence and burial during initiation of the offshore sedimentary basins, with the possibility that the successions now seen therein might have originally encroached onto the present onshore region. The subsequently identified Early Cretaceous magmatism (Stone et al. 2008. see Section 6, below) might also have played a part. Late Cretaceous and/or Early Palaeogene cooling followed regional uplift associated with large-scale tectonic adjustments along the southern margin of the Falkland Plateau, at the North Scotia Ridge Transform Fault (Fig. 1).

\section{Mesozoic dyke swarms}

\subsection{Discovery and distribution}


Mafic dykes are a common feature in West Falkland, but are comparatively rare in East Falkland. The first definitive observations were made, most probably in 1844, by Captain (later Admiral Sir) Bartholomew Sulivan during a survey voyage by HMS Philomel (Stone \& Rushton 2013). Sulivan had previously served on HMS Beagle, had become firm friends with Darwin during that voyage, and wrote to Darwin from HMS Philomel reporting his new geological discoveries in West Falkland. The dyke descriptions are contained in a letter dated $13^{\text {th }}$ January to $12^{\text {th }}$ February 1845 (Darwin Correspondence Number 730, Burkhardt \& Smith 1987). Sulivan wrote of “[n]umerous dykes running perpendicular in a North and South direction” and commented that "there are hundreds of these dykes running miles in length . . . . and some are twenty feet wide, and all sizes from that down to two inches”. Darwin received Sulivan's letter in time to add a footnote - "Captain Sulivan observed on the western island numerous basaltic dykes" - to his 1846 paper "On the geology of the Falkland Islands”, which had been presented at a meeting of the Geological Society of London on March $25^{\text {th }}$ of that year.

With only Darwin's rather vague, 1846 footnote as a published guide, the full extent of the West Falkland dyke swarm remained unappreciated and did not become apparent until more detailed geological investigations in the early twentieth century by Andersson (1907), Halle (1911) and Baker (1924), the last of whom reported dyke trends as varying from NNE-SSW around to WNW-ESE and suggested that they all shared a radial disposition emanating from a point somewhere to the east of Cape Meredith, the southern extremity of West Falkland (Fig. 2). This proposal was negated by the photo-interpretation of Greenway (1972) who identified up to 400 individual dykes on West Falkland and separated them into two distinct but intersecting swarms: NNE-SSW dykes occurred mostly in the north and centre of the island whereas WNW-ESE dykes were confined to the south. A more variable pattern in the SW of West Falkland, around Cape Orford and on Weddell Island, was described by Greenway as an area of overlap. Aldiss \& Edwards (1999) mapped and described the West Falkland dykes in terms of six swarms defined on the basis of petrographic detail, orientation, distribution and field characteristics. They referred the NNE-SSW dykes to a Sulivan Swarm, divided the WNW-ESE dykes into a northern Fox Bay Swarm and a southern, South Harbour Swarm, and formalised the Cape Orford Swarm as a more varied assemblage than had been previously 
appreciated. Two other swarms were of relatively restricted extent on outlying islands to the west of West Falkland. Nevertheless, the dominant, regional pattern of dyke orientation established by Aldiss and Edwards was not fundamentally at odds with the previously established trends. Dyke thickness is mostly commonly in the range of a few metres to a few tens of metres, but some are several hundred metres across whilst many are only a few centimetres wide.

Except at the coast, many of the dykes are only very poorly exposed and until the end of the $20^{\text {th }}$ century very few had been recorded from East Falkland where, in addition, potential aerial photograph lineaments were obscured by the generally thick cover of superficial material. Those few dykes that were seen appeared to broadly follow the NNE-SSW trend. Thereafter, a commercial aeromagnetic survey flown in 2004 detected more dykes (on the basis that dolerite dykes were the cause of the sharp, linear anomalies seen) and suggested an additional sub-division of the swarms (Stone et al. 2008; Stone 2013). Across West Falkland the aeromagnetic survey allowed the NNE-SSW dykes to be resolved into two discrete and intersecting swarms: dykes forming one of the swarms run N-S whilst the dykes defining the other swarm trend broadly NE-SW (Fig. 10). The latter is widespread in West Falkland with a few outlying members present in East Falkland. The N-S swarm comprised about 40 dykes spaced equally (albeit exposed only very rarely) across both East and West Falkland. In East Falkland the dykes of the N-S swarm swing into a more NNW-SSE orientation as they are traced northwards on the basis of their linear anomalies.

The distribution of linear aeromagnetic anomalies suggest a much greater dyke density than had been previously recorded, but there are nevertheless a few wellknown dykes running broadly N-S in the northern part of West Falkland that do not appear to lie on linear anomalies (cf. Aldiss \& Edwards 1998). The explanation for this apparent mismatch probably lies in the distribution and orientation of the airborne survey's flight lines which, across much of West Falkland, ran N-S and had a spacing of $500 \mathrm{~m}$. However, in a $10 \mathrm{~km}$-wide strip in the NE of that island, technical problems resulted in a line spacing of $1 \mathrm{~km}$. The 'missing' anomalies mostly lie within this zone and their absence from the airborne results is probably the result of their source dykes being parallel to the widely spaced, N-S flight lines. Even with the more closely 
spaced flight lines, their parallelism with the N-S dykes creates an issue of poor anomaly resolution that requires careful interpretation.

Perhaps uniquely for the Falkland Islands, the small South Fur Island (between West Point Island and the Jason Islands, Fig. 2) appears to be formed from a dolerite sill intruded into felsic tuff. Aldiss \& Edwards (1999, 58-61) associate the sill with the Early Jurassic dykes and from this relationship, coupled with the distribution of distinctive beach pebbles on the West Falkland coast, speculate that a bimodal, Jurassic volcanic suite may crop out on the sea floor in the north-west part of the archipelago.

\subsection{The ages of the dyke swarms}

A Jurassic age for West Falkland dykes was first established by radiometric dating of dykes from the vicinity of Cape Meredith. These gave K-Ar dates of $192 \pm 10 \mathrm{Ma}$ (Cingolani \& Varela 1976) and 176 \pm 7 Ma and 162 \pm 6 Ma (Thistlewood et al. 1997) for the NE-SW trending swarm. More precise Ar-Ar dates were reported by Mussett \& Taylor (1994): a dyke from the Cape Orford swarm gave 190 \pm 4 Ma, an E-W dyke gave $188 \pm 2$ Ma, and a NE-SW dyke gave a maximum age of 193 \pm 4 Ma (Fig. 3). These three Ar-Ar dates were regarded as indistinguishable within error, and were taken to show intrusion of all of the West Falklands dykes at about 190 Ma during the Early Jurassic. An Ar-Ar date of 178.6 \pm 4.9 Ma was obtained by Stone et al. (2008) from the NE-SW dyke at Port Sussex in East Falkland (Fig. 10). This age is compatible with the Ar-Ar maximum age of c. 193 Ma reported by Mussett \& Taylor (1994) from a NE-SW dyke in West Falkland, but is more closely aligned with the KAr date of about 177 Ma reported by Thistlewood et al. (1997) from Cape Meredith.

The N-S dyke swarm identified from the aeromagnetic survey proved to be of a younger, Early Cretaceous age. The first result, an Ar-Ar date of 121.3 $\pm 1.2 \mathrm{Ma}$ (Aptian) was reported by Stone et al. (2008) from the east side of East Falkland (Fig. 10, Pony's Pass Quarry (Fig. 9f)); a second series of Ar-Ar dates reported from two other dykes on the west side of East Falkland (Fig. 10, Teal Creek and Peat Banks) by Richards et al. (2013) ranged between $131 \pm 4$ Ma and 138 \pm 4 Ma (Valanginian to Hauterivian). The difference might raise questions about the homogeneity of the 
Cretaceous dyke swarm and of relevance in that respect is the variation in palaeomagnetic polarity shown by the aeromagnetic anomalies. Across the whole N-S swarm, the eastern dykes show reversed magnetic polarity but the majority of those further to the west have normal polarity. Of the two dated, ca 131-138 Ma dykes, the polarity of one is reversed whilst that of the other is normal. The overlapping ages of these dykes suggests that magmatism lasted long enough to span a magnetic reversal, of which there were several at around that time. The apparently younger N-S dyke has reversed polarity, though the $121 \mathrm{Ma}$ age places it within the early part of the normal polarity Cretaceous super-chron, the so-called Cretaceous quiet zone. This contradiction raises some doubt as to the date's validity.

\subsection{Compositions of the different dyke swarms}

All of the Cretaceous dykes are petrographically very similar plagioclaseclinopyroxene-orthopyroxene dolerites with a characteristic glassy groundmass. They are distinct from the Jurassic dykes which mostly fall into two categories: those forming the E-W swarm are plagioclase-clinopyroxene-olivine dolerites, whereas the NE-SW dykes are plagioclase-clinopyroxene-orthopyroxene dolerites lacking the glassy matrix characteristic of the Cretaceous dykes; the Cretaceous dykes are also markedly Fe-rich relative to all of the Jurassic examples (Mitchell et al. 1999; Stone et al. 2008). The geochemical similarities and contrasts are illustrated in Fig. 11 as a series of variation diagrams for selected major and trace elements plotted against MgO. Data for the dated East Falkland dykes (Stone 2013) are superimposed on fields derived for the West Falkland, Jurassic dykes by Mitchell et al. (1999); also included are results from the NE-SW-trending and low-Fe (and so presumed Jurassic) Lively Island dyke (Figs $2 \& 10$ ), an unusual occurrence from which the similarity of results demonstrates the compatibility of the two datasets. Two dykes identified by Mitchell et al. from the south of West Falkland as having an unusual, 'evolved' character, but still presumed by them to be Early Jurassic, have some compositional similarities with the subsequently-identified Early Cretaceous swarm, but the given localities do not appear to be associated with appropriately N-S aeromagnetic anomalies. 
The results from Mitchell et al. (1999) clearly demonstrate that there are systematic differences between the Jurassic NW-SE and E-W dyke swarms of West Falkland (Fig. 11). The East Falkland Cretaceous dykes form a distinct cluster in a range of element ratios with no overlap into the Jurassic fields. Despite the apparent variation in their ages, there are no significant compositional differences between the N-S dykes from the east and west sides of East Falkland.

The Early Jurassic Cape Orford dyke swarm was described by Mitchell et al. (1999) as comprising highly altered, broadly andesitic rock types; Aldiss \& Edwards (1999) reported a greater variety, ranging from feldsparphyric dolerite to probable rhyolite. Aldiss \& Edwards also suggested that two additional, localised dyke swarms, both of doleritic lithologies, were present on outlying islands to the west of West Falkland: New Island and Saunders Islands. Information on these is sparse and they lie beyond the western margin of the aeromagnetic survey. It seems very likely that the dyke swarms in West Falkland are more complex than currently appreciated and would be well-worth further investigation.

\section{The Falkland Islands in Gondwana}

\subsection{The historical perspective}

Following the work of Halle (1911) and Baker (1924) the close association of Falkland Islands geology with that of South Africa was generally appreciated. In both areas, a similarly-aged metamorphic basement was overlain by a Palaeozoic sedimentary succession containing a 'Malvinokaffric' fossil assemblage. The deformed strata of the West Falkland Group corresponded to the Cape Fold Belt, the less-deformed Lafonia Group to the Karoo Basin, whilst both areas were intruded by swarms of mafic dykes. By way of explanation Baker had invoked the continental drift ideas championed by Wegener in a series of publications from 1912 onwards, but which would have been topically accessible to Baker when an English translation of the third edition of Wegener's book Die Ehtstehung der Kontinente und Ozeane (Wegener 1922) was published in 1924. Baker did not propose any palaeogeographical reorganisation to accommodate the regional correlations, which 
was left to Du Toit (1927), who went on to become continental drift's most influential advocate with publication of Our Wandering Continents (Du Toit 1937).

It was not just the Falkland Islands that were geologically similar to South Africa. Keidel (1916) had noted the correlation of the South African geology with that of the Ventania System (sensu Alessandretti et al. 2013) of Argentina. When Du Toit (1927, 1937) reconstructed a pre-Atlantic Gondwana, these two regions were aligned into a single fold belt and basin. But that left the Falkland Islands isolated a long way to the south, and Du Toit's revolutionary solution was to move them northwards until they sat between the Sierra de la Ventana (the fold belt wherein forms part of the Ventania System) and the Western Cape (Fig. 12a). This solution did not find much support. The rejection of continental drift by the geological mainstream has been welldocumented (e.g. Newman 1995; Oreskes 1999) and the majority view at the end of the 1920s was illustrated by Gregory (1929) in his Presidential Address to the Geological Society of London. Therein, Gregory portrayed Gondwana as encompassing Africa, South America and a huge landmass between them that had subsided beneath the waters of the South Atlantic Ocean; the Falkland Islands were seen as a marginal vestige of that landmass.

\section{Figure 12 about here}

Despite the generally dismissive view of continental drift held by the geological mainstream throughout the first half of the $20^{\text {th }}$ century it did have its champions, particularly amongst geologists with southern hemisphere experience. Notable advocates were Arthur Holmes (UK), Lester King (South Africa) and S. Warren Carey (Australia), whilst many of those geologists active in the South Atlantic region also viewed the process as an attractive explanation for the regional geology (Stone 2015). For the Falkland Islands, the most radical proposal came from Adie (1952a) who aligned structural and sedimentological trends to support the rotation of a Falkland Islands continental block through about $180^{\circ}$ from an original position adjacent to the east coast of South Africa (Fig. 12b). Adie's solution was largely ignored, particularly when early plate tectonic reconstructions appeared to successfully model the opening of the Atlantic Ocean with the Falkland Islands and Plateau left as a continental promontory from southern South America (e.g. 
Rabinowitz \& LaBrecque 1979; Martin et al. 1981). This changed when the apparently independent movement of the Falkland Islands was rediscovered in terms of microplate rotation supported by palaeomagnetic data (Mitchell et al. 1986).

\subsection{The South African connection}

The well-established correlation between Falkland Islands and South African stratigraphy (Halle 1911; Baker 1924; Adie 1952a and b) is summarised in Table 1. The Proterozoic rocks of the Cape Meredith Complex have counterparts in the Namaqualand-Natal Metamorphic Complex (NNMC), although there are some differences in age (reviewed by Aldiss \& Edwards 1999) and similarities with the Deseado Massif of Patagonia have also been noted (Borrello 1963; Ramos 2008). The metamorphic basement of the Maurice Ewing Bank, proved during DSDP leg 36 (Tarney 1977), could also be related to the NNMC and so enabled all of the Falkland Plateau, prior to its extension, to be positioned in the Natal embayment, between South Africa and East Antarctica (Fig. 4).

Correlations of the sedimentary successions of the Falkland Islands and South Africa are particularly compelling. Detailed comparisons have been drawn between the Port Stephens Formation and the Nardouw Subgroup, the upper part of the Table Mountain Group (Hunter \& Lomas 2003) and between the Lafonia Group and the Dwyka, Ecca and Beaufort groups of the Karoo Basin (Trewin et al. 2002). The faunal and lithofacies similarities between the Fox Bay Formation and the Bokkeveld Group were apparent to the earliest workers (e.g. Sharpe \& Salter 1856) and were influential in shaping Adie's (1952a) model - as a South African, Adie had arrived in the Falklands well-primed in the relevant geology. Another well-established (Halle 1911) pair of correlative units is the glacigenic beds deposited during the PermoCarboniferous glaciation of southern Gondwana: the Fitzroy Tillite Formation and the diamictites of the Dwyka Group, both deposited during the Early Permian. The general lithofacies similarity extends to the erratic content, including such details as the detrital zircon population (Craddock \& Thomas 2011) and the archaeocyathid assemblage in exotic clasts of Early Cambrian limestone (Stone \& Thomson 2005; Stone et al. 2012). All of the archaeocyathan limestone was thought to have originated in the Transantarctic Mountains, but recent discoveries in Argentina 
(González et al. 2012) have added a new dimension to the regional picture that is not yet fully appreciated.

In South Africa, the Cape Fold Belt and Karoo Basin are generally regarded as having developed as a retroarc fold and thrust belt verging northwards with a preceding foreland basin (e.g. Catuneanu et al. 1998 and references therein). An alternative interpretation (Tankard et al. 2009, 2012) points to perceived weaknesses in that model and regards the Cape Fold Belt as a sinistral strike-slip orogen driven by the reactivation of deep basement structures, with only the later part of the Karoo succession deposited in a foreland basin environment. Whichever version is preferred for southern Africa, to the west, in Argentina, regionally correlative and structurally N-verging geotectonic features now form the Ventania System: the Sierra de la Ventana fold and thrust belt and the Claromecó foreland basin (e.g. Milani \& de Wit 2008; Alessandretti et al. 2013). When rotated into a position off the east coast of South Africa - the Adie (1952a) model (Fig. 12b) - the Falklands fold belt and Lafonia basin (S-verging in their current position) become, respectively, the eastern extension of the N-verging Cape Fold Belt and the otherwise missing, SE corner of the Karoo Basin. More detailed similarities in the structural history of the Falkland Islands and South Africa were stressed by Curtis and Hyam (1998), but it was new information from the Falkland Islands dyke swarms that had first rejuvenated Adie's rotational model.

There is an undisputed regional association of the Early Jurassic dykes from the Falkland Islands, dated ca 178-184 Ma, with the Karoo-Ferrar magmatism in South Africa and Antarctica: Karoo magmatism peaked at c. 183 Ma with the peak of Ferrar magmatism a little later at about 180 Ma (e.g. Encarnación et al. 1996; Duncan et al. 1997; Riley \& Knight 2001). Mitchell et al. (1999) showed that the Falklands Jurassic dykes marked an overlap between the Karoo and Ferrar provinces, with the E-W Falklands swarm made up of Karoo-type dolerite and the NE-SW Falklands dykes showing more affinity to Ferrar-type dolerite (Fig. 4); the latter association had also been noted by Thistlewood et al. (1997). A popular hypothesis for the generation of the Early Jurassic, Karoo magmatism that spanned the South African and Antarctic (Dronning Maud Land) segments of Gondwana, associated it with a mantle plume responsible for initiating the break-up of that supercontinent (e.g. Storey et al. 1999); 
whilst the regional picture may well be more complicated, the involvement of a focused thermal anomaly is highly likely (Storey et al. (2013). In contrast, the origin of the Ferrar igneous province remains unresolved. Its linear outcrop parallel to the active, 'Pacific' margin of Gondwana (Fig. 4) invites an association with subduction, but the distance from the active margin is unusually large and other models have been proposed, as reviewed by Storey et al. (2013).

The Early Cretaceous dykes from the Falkland Islands, with ages in the range $135 \mathrm{Ma}$ to $121 \mathrm{Ma}$, are more likely to have arisen from magmatism generated during the subsequent, early stages of Atlantic Ocean rifting. Richards et al. (2013 and references therein) drew comparisons with the c. 134 to 129 Ma Paraná-Etendeka flood basalts and associated dykes, which are now preserved much further north on opposite sides of the South Atlantic (Brazil and Angola/Namibia), and to the c. 131 Ma dyke swarm that occurs in the Cape Peninsula - False Bay area of SW South Africa.

Independent rotation of a Falklands microplate has implications for its relationship with the rest of the Falklands Plateau, and in particular with the Maurice Ewing Bank which would also need to be regarded as an independent microplate. Originally in close proximity (Fig. 4), considerable extension between them would have been needed to create the present-day dimensions of the Falkland Plateau. Marshall (1994a \& b) suggested Early Jurassic extension preceding rotation of the Falklands microplate; Macdonald et al. (2003) saw the extended area as a failed rift that developed post-rotation. The latter explanation could also be applied to a fixed, nonrotational interpretation of the region to satisfy some of the space problem inherent in plate reconstructions that utilise the current dimensions of the plateau. In either case, extension might well correlate with the intrusion of the Early Cretaceous dyke swarm seen onshore in the Falkland Islands.

\subsection{Palaeomagnetism}

An overlap between Karoo-type and Ferrar-type magmatism would be compatible with the position of the rotated Falkland Islands in Gondwana, when the islands would lie between South Africa and East Antarctica. But the more compelling 
evidence for rotation presented by Mitchell et al (1986), and then in more detail by Taylor \& Shaw (1989), was derived from the palaeomagnetic record in the Falkland Islands' Early Jurassic dykes. Although described rather dismissively as 'meagre’ by de Wit (1992), this data supported a substantial clockwise rotation of the Falklands microplate by about $100^{\circ}$, with systematic differences in the characteristic remanence directions between the three principal Early Jurassic swarms. The differences were taken to show intrusion during rotation, but it was subsequently established that there was little difference in the ages of the dykes concerned (Mussett \& Taylor 1994).

In an attempt to clarify the situation, Thistlewood \& Randall (1998) reported the palaeomagnetic properties of the Falklands sedimentary succession. The West Falkland Group gave no useable results, but some samples from the Port Sussex Formation (Lafonia Group), despite modern overprinting, preserved a remanent magnetisation requiring rotation of approximately $100^{\circ}$ into the current orientation. Nevertheless, when in a subsequent study Hodgkinson (2002) was unable to repeat the palaeomagnetic results, he noted that the NE-SW dykes, and possibly others, were intruded into a transpressive regime and that shearing had affected the minerals on which the palaeomagnetic measurements relied. Hodgkinson therefore questioned their reliability, but additional evidence in support of rotation was then derived from the aeromagnetic survey results by Stone et al. (2009). They showed that the differing asymmetries of the linear magnetic anomalies associated, respectively, with the NESW Early Jurassic dykes, and the N-S Early Cretaceous dykes were most compatible with a $120^{\circ}$ rotation of the host block between the intrusions of the two swarms.

\section{The offshore sedimentary basins}

Seismic refraction profiles had been shot across the Falklands area in the late 1950s as part of an academic research project based at the Lamont-Doherty Geological Observatory (now Earth Observatory) of Columbia University, City of New York. These were followed by more seismic experiments during the early 1970s, culminating in 1974 in the drilling of three boreholes on the Maurice Ewing Bank, some $600 \mathrm{~km}$ to the east of the Falkland Islands (Fig. 1), as part of the international Deep Sea Drilling Project, Leg 36. Amongst the discoveries made, the boreholes proved the existence of a potential oil source rock, and so encouraged more 
commercial interest. During the 1977-78 austral summer two speculative, regional seismic surveys were shot around the Falkland Islands but the data acquired remained proprietary and were not made publically available.

Following the invasion and temporary occupation of the Falkland Islands by an Argentine military force in 1982 it was not until the early 1990s, and with the British Geological Survey having been appointed by the Falkland Islands government to help manage and promote hydrocarbon activity, that renewed interest in the offshore potential led to the acquisition of more speculative seismic data to both the north and south of the archipelago. In 1996 the first Production Licenses were awarded for acreage to the north, in the North Falklands Basin, and initiated the more focussed exploration programmes that continue today. The location of the sedimentary basins under investigation is shown in Fig. 1; their geology was reviewed by Richards et al. (1996). Since then they have been the subject of extensive seismic surveys and a number of exploration wells have been drilled, mostly in the North Falklands Basin. With only a few exceptions, the data collected are held on a confidential basis by the companies concerned and are commercially sensitive. Nevertheless, the general configuration of the sedimentary basin network surrounding the Falkland Islands has been confirmed. They all contain a Jurassic and younger sedimentary succession that lies either on strata equivalent to the onshore West Falkland and Lafonia groups, or on possible Jurassic volcanic rocks. Aldiss \& Edwards $(1999,60)$ argued for the presence of a Jurassic, bimodal volcanic suite at outcrop on the sea floor in the north-west coastal zone of the archipelago, but this has not yet been confirmed.

This review attempts to provide a broad, regional summary of the basins' structure and stratigraphy. It does not consider detail of the specialist petroleum geology.

\subsection{North Falklands Basin}

To the north of the Falklands archipelago, the North Falklands Basin is a classic example of a failed-rift basin (Fig. 13a) with two main structural components (Richards \& Fannin, 1997; Richards \& Hillier 2000a \& b; Lohr \& Underhill 2015). An elongate area of subsidence controlled by extensional faults running approximately N-S (the North Falkland Graben) is from 20 to $40 \mathrm{~km}$ wide and about 
$250 \mathrm{~km}$ long, with the southern margin only some $35 \mathrm{~km}$ north of the islands. To the S and SW of the graben is another area of subsidence controlled partly by N-S extensional faults and partly by NW-SE extensional faults thought to be influenced by the reactivation of structures that originated as compressional thrusts in the underlying Palaeozoic rocks. Reactivation of this sort has been described from the West Falkland Group at the onshore northern margins of East and West Falklands.

\section{Figure 13 about here}

There have now been three drilling campaigns in the North Falklands Basin, the first in 1998 with six wells, the second in 2010-2011 with 16 wells, and the third in 2015 with 5 wells. Of these, at least six have made potentially commercial hydrocarbon discoveries and a thematic set of papers devoted to the petroleum geology of the highly promising Sea Lion Field has been published recently in Petroleum Geoscience (2015, 21 (2-3), 83-209). As a result of the drilling campaigns, and with the additional data generated by detailed seismic surveys, the regional structure and stratigraphy of the basin are becoming clearer. Subsidence probably began with E-W extension during the Jurassic and into the earliest Cretaceous, commensurate with the initial break-up of Gondwana. Then, through the Early Cretaceous, subsidence continued as thermally-driven basin sag. In some parts of the basin subsidence gave way to localised and intermittent uplift during the Cretaceous as a distant effect of the rise of the Andean Cordillera and the related initiation of uplift along the North Scotia Ridge farther to the south.

Lohr \& Underhill (2015) stress the different structural histories of the North Falkland Graben, and the sub-basin on its SW flank, describing them as two separate but transecting rifts and proposing that they should be differentiated as the Northern and Southern Rift basins. The Southern Rift Basin was interpreted as the older of the two, initiated in the Late Jurassic and controlled by faults striking NW-SE. The Northern Rift Basin was initiated a little later by N-S faults, which are underlain at depth by structures related to the northern extension of the Southern Rift Basin. The southern extension of the Northern Rift Basin, originally superimposed on the southern rift, has been largely removed by erosion following uplift in the forebulge region developed in association with plate margin tectonics farther south at the North Scotia Ridge 
transform fault. Within the same regional tectonic pattern subsidence continues across the North Falklands Basin’s northern rift.

The Jurassic and earliest Cretaceous sedimentation took place in fluvial plains, associated alluvial fans and ephemeral lakes. Thereafter, through much of the Early Cretaceous, a large and permanent lake system occupied the central part of the North Falkland Graben (Northern Rift Basin); analogies have been drawn with Lake Malawi in the present-day East African Rift (Richards \& Hillier 2000a \& b). The North Falkland Graben lake most probably reached depths of over 500 metres in places and had a stratified water column, with an oxygenated upper layer supporting some fish and algal life but a stagnant, anoxic bottom layer. From the north, the basin was filled by a large sandy delta; smaller deltas extended from other parts of the basin margins but elsewhere these merged laterally with swampy alluvial plains (Richards et al. 2006). The sedimentary deposits filling the basin, up to and possibly exceeding $10 \mathrm{~km}$ in thickness, are dominantly lacustrine and deltaic clay, mudstone and turbiditic sandstone in the lower part of the succession and fluvial sandstones in the upper part. Some of the mudstones are highly organic and are the source rocks for the basin's hydrocarbons. From the Late Cretaceous onwards, the succession becomes progressively more marine, with several sandstone intervals showing high-quality reservoir properties.

\subsection{The southern basins}

To the south of the Falkland Islands three basins are identified, although they are structurally linked along their southern margins by interaction with the major structural boundary between the Falklands microplate/plateau and the Scotia plate to the south. Despite this common feature the structure of each basin has unique elements, and they all differ markedly from the 'failed-rift' structural configuration seen in the North Falklands Basin.

To the SE of the Falklands archipelago, the Falkland Plateau Basin is a passive margin-type basin on the SE flank of the Falkland Plateau; it is bordered to the south by the Burdwood Bank and to the east by the Maurice Ewing Bank (Fig. 1). The basin 
contains a succession of Late Jurassic to Cretaceous strata, up to about $15 \mathrm{~km}$ thick, which has so far been examined by only four commercial wells. At its eastern extremity, the basinal strata extend onto the Maurice Ewing Bank where DSDP borehole 330 showed them to lie unconformably on Proterozoic crystalline rocks. Elsewhere in the basin, seismic evidence has been interpreted as showing that the Jurassic to Cretaceous sedimentary succession overlies rocks akin to those of the onshore West Falkland and Lafonia groups. Seismic basement was sampled in 2010 by a commercial well that terminated at $2476 \mathrm{~m}$ below sea level in aphyric, plagioclase-clinopyroxene-olivine dolerite of similar petrographic character to that forming the E-W, Early Jurassic dykes onshore (Richards et al. 2013). If this association is correct it would make the 'seismic basement' dolerites part of the Early Jurassic and pre-Atlantic, Karoo-Ferrar magmatism. A somewhat different interpretation arises from the proposals by Marshall (1994b) and Barker (1999) that the offshore, SE margin of the Falkland Islands block was a volcanic, rifted continental margin, and that oceanic crust was created between the Falklands and Maurice Ewing microplates during extension of the Falkland Plateau; a Late Jurassic or Early Cretaceous age might then seem more likely for the 'seismic basement' dolerites. The presence of a thick doleritic 'basement' beneath the Falkland Plateau Basin, generated either as oceanic crust or during Karoo-Ferrar 'underplating' and replacement of thin continental crust, received additional support from gravity modelling reported by Kimbell \& Richards (2008) and seismic refraction observations by Klemt \& Jokat (2015). The high heat-flow regime that would have existed during basin extension and oceanic crust formation was thought by Marshall (1994b) to have much reduced the hydrocarbon potential of the Falkland Plateau.

Richards et al. (1996) dated the relatively thick (up to about $3 \mathrm{~km}$ ) succession of Jurassic to Early Cretaceous rocks in the Falklands Plateau Basin by extrapolation of the seismic profiles back to the DSDP boreholes on the Maurice Ewing Bank. The succession is interpreted as a marine series of deltaic or shelf margin fan systems prograding and thickening towards the SE, where they merge with possible slump masses and/or basin-floor turbidite deposits (Richards et al. 2006). The oldest of the fan units is possibly of Late Jurassic age; four successive Cretaceous fans, tentatively dated as Albian to Cenomanian, then step successively farther into the Falkland Plateau Basin. 
Within the Falkland Plateau Basin succession, a series of high amplitude seismic reflectors are interpreted as sills and/or lava flows and ascribed a probable Early Cretaceous age. This age interpretation was made by Richards et al. (1996) despite the evidence then available suggesting that only dykes of Early Jurassic age were present onshore in the Falkland Islands. Their interpretation was based on the offshore sills being intruded into Jurassic rocks and so of necessity being younger than their hosts. Richards et al. extended that argument to suggest that some of the onshore dykes may also prove to be of Early Cretaceous rather than Early Jurassic age, and so genetically linked to the opening of the South Atlantic. This inference has been justified by the subsequent discovery of Early Cretaceous dykes onshore, as documented in Section 6 of this review. It is likely that these onshore dykes are related to regional stresses associated with South Atlantic opening rather than to Gondwana fragmentation; it seems logical that lava extrusion and/or sill intrusion offshore during the Early Cretaceous, in the Falkland Plateau Basin, would be related to the same regional stress field (Richards et al. 2013).

At its SW extremity, the Falkland Plateau Basin runs into a narrower zone of subsidence adjacent to the northern edge of the Scotia Plate. There, the major fault complex separating the Scotia plate and Burdwood Bank to the south, from the Falklands Plateau to the north, is a complicated plexus of extensional, compressional and sinistral strike-slip components - the North Scotia Ridge Transform Fault. Smalley et al. (2003) demonstrated active sinistral movement of $6.6 \pm 1.3 \mathrm{~mm} / \mathrm{year}$ in the Tierra del Fuego sector of the Fault, but found no evidence for active transpression. To the south of the Falkland Islands, earlier compressional effects resulted in $\mathrm{N}$-directed thrusting and the creation of a foredeep and a foreland basin on the north side of the fault zone (Fig. 13b). This is the South Falkland Basin (Richards et al. 1996; Bry et al. 2004), where two wells were drilled in 2012; one in the fold and thrust belt itself and one in the foreland basin. Most of the basinal succession comprises a relatively thick series of Mesozoic, probably marine sandstones and mudstones, overlain by a thinner Cenozoic accumulation of similar lithologies; together they form a succession up to about $6 \mathrm{~km}$ thick. To the west, and to the SW of the Falklands archipelago, the basin opens out into a broader zone of subsidence, mostly in Argentine waters, known as the Malvinas Basin. 
As suggested in Section 4.2.1, on the north side of the foreland basin the forebulge development probably contributed to the uplift of the Siluro-Devonian, West Falkland Group strata that forms the small, isolated Beauchêne Island and the surrounding, southernmost inlier of Siluro-Devonian rocks (Fig. 1b).

\section{Onshore Neogene}

There has been speculation that the Mesozoic-Cenozoic strata of the offshore sedimentary basins may once have encroached onto what is now the onshore area (Thomson et al. 2002; see Section 5.4). Be that as it may, the only possible Cenozoic deposit now preserved in the Falkland Islands is the terrestrial West Point Forest Bed, and its origin has been much debated. It is a clay layer packed with tree debris and found beneath solifluction deposits close to sea level on West Point Island, West Falkland (Fig. 2). Halle (1911) thought it to be the remains of an in situ, pre-glacial tree cover, whereas Baker (1924) concluded that it was simply a buried accumulation of driftwood. Recently, a very detailed study by Macphail \& Cantrill (2006) has supported Halle's interpretation and indicated a Neogene, Mid Miocene to Early Pliocene age based on the time distribution of a number of rare pollen types and the present-day ecology of their nearest living relatives in South America. The bed derived from a wet, temperate rainforest dominated by species of Southern Beech (Nothofagus). It is likely that at the time of its growth this forest community covered much of the Falkland Islands.

\section{Did a Falklands microplate rotate?}

Despite the compelling evidence in favour of microplate rotation this remains the most controversial question in Falklands geology. From the perspective of the onshore geology, regional Gondwana relationships can only be reconciled by clockwise rotation of a Falklands microplate away from an original position adjacent to what is now the SE coast of South Africa (Figs 4 and 12b). From the offshore basins a wealth of seismic and well evidence has now been generated but there are no indications therein of the extension and compression that might be expected to have accompanied block rotation. This absence is commonly taken as being compatible with a 
Gondwana break-up history in which the archipelago remained part of a Falkland Plateau fixed as a promontory from the South American margin albeit one that has undergone much extension, perhaps as much as 280\% (Lorenzo \& Mutter 1988). The former, mobile interpretation requires about $180^{\circ}$ of rotation $\left(150^{\circ}\right.$ during break-up of Gondwana, $30^{\circ}$ during opening of the South Atlantic) from an original position adjacent to the east coast of South Africa (after Adie 1952a); the latter 'rigid' interpretation incorporates something like $60^{\circ}$ of rotation simply as a result of the opening of the Atlantic Ocean, with the Falkland Islands originating some $300 \mathrm{~km}$ south of the Cape of Good Hope (e.g. Richards et al. 1996; Lawrence et al. 1999; Ramos 2008). However, in this debate timing is crucial and it would seem very likely that most of the rotation of the Falklands microplate was certainly pre-Cretaceous (and probably mid-Jurassic) and so occurred before much of the extension recorded by the offshore sedimentary basins (e.g. Stone et al. 2009; Dalziel et al. 2013). Hence there is no reason to expect much, if any, manifestation of rotation in the Late Jurassic and younger sedimentary basins.

The original rotational model of Adie (1952a) provoked little reaction when first published, faded into obscurity, and was overlooked when early plate tectonic reconstructions appeared to successfully satisfy the opening of the Atlantic Ocean with the Falkland Islands and Plateau left in their current situation as a continental promontory from southern South America (e.g. Rabinowitz \& LaBrecque 1979; Martin et al. 1981). This changed when palaeomagnetic evidence from Falkland Islands dykes instigated the rediscovery of the Adie model in terms of microplate rotation (Mitchell et al. 1986; Taylor \& Shaw 1989). The reliability of the palaeomagnetic results from the Falklands dykes has been challenged (e.g. Hodgkinson 2002) but was supported by the data from the Permian Port Sussex Formation (Thistlewood \& Randall 1998); unfortunately much of this work has not been formally published. Another important influence was the discovery of a continental metamorphic basement to the Maurice Ewing Bank during DSDP leg 36 (Tarney 1977) and the appreciation of its pre-drift location within the Natal embayment.

In one way, the debate over rotation of a Falklands microplate has shadowed the earlier arguments over continental drift in that, if rotation has occurred, a mechanism 
is required. There have been several attempts to address this issue which have invoked a variety of mechanisms. The rotation of small microplates during extension driven by doming above a Karoo thermal plume features in several interpretations as summarised by Storey et al. (1999, 2013 and references therein), whilst Dalziel \& Lawver (2001) argued for widespread crustal extension driven by the high heat flows associated with Karoo and Ferrar magmatism, Conversely, from a plate kinematic analysis, Eagles and Vaughan (2009) disputed the need for Karoo magmatism to act as a driving force for continental break-up and noted the apparent absence of basinmargin structures that might be expected to accompany extension and rotation. Other interpretations (e.g. Ben-Avraham et al. 1993; Marshall 1994a; Macdonald et al. 2003) have involved extension of the Falkland Plateau in association with large scale dextral movement on the Aghulas Fracture Zone (Fig. 4). Extended westward, this fracture zone can be linked with the Gastre Fault cutting South America, allowing the southern part of that continent to have originally been positioned much closer to Africa. Any space problem is then alleviated by closing-up the Falkland Plateau Basin which becomes a site of Late Jurassic sea-floor spreading. In this context, rotation would have been a relatively rapid, mid-Jurassic event. However, Tankard et al. (2012) have pointed out that there is no evidence for significant movement on the Aghulas Fracture Zone at that time. For that reason, and coupled with both the absence of clearly defined microplate boundaries and a lack of structural evidence for rotation, Tankard et al. preferred the 'rigid' model of a fixed Falklands Plateau extending from the South American continent. Thomson (1998) made a case for Early Cretaceous rotation of a Falklands microplate following initiation of the offshore basins but subsequently acquired data would seem to preclude this possibility.

In a comprehensive overview of Gondwana break-up in the South Atlantic and Weddell Sea region, Dalziel et al. (2013) stressed the importance of the opposed senses of rotation between their Lafonian (= Falklands) microplate (clockwise) and the Ellsworth-Whitmore Mountains microplate (anticlockwise): the subduction rollback, ‘double-saloon-door' model of Martin (2007). Like the Falklands microplate, the Ellsworth-Whitmore block originated in the Natal embayment (Fig. 4), and so aspects of its geology bear comparison to that of the Falklands (e.g. Webers et al. 1992), but it was rotated away from its erstwhile neighbour to become incorporated in West Antarctica, during a mid-Jurassic phase of extreme extension. 
The tectonic history of West Antarctica is well beyond the scope of this review but, as a corollary for argument in favour of the rotation of a Falklands microplate, it is worth noting that there is good evidence for substantial anticlockwise rotation of the Ellsworth-Whitmore Mountains microplate (Grunow et al. 1987; Randall \& Mac Niocaill 2004). In the interpretation of Dalziel et al. (2013) the two are inescapably linked: "the Lafonian [Falklands] and Ellsworth-Whitmore Mountains crustal blocks moved as part of allochthons on low-angle detachment faults on continental crust and mantle ... that were extending in a ductile fashion above a rapidly retreating subduction zone” (op.cit. p. 773). These major rotations, and hundreds of kilometres of lateral microplate movement, occurred before any seafloor spreading and so preceded opening of the South Atlantic Ocean.

From the author's predominantly onshore perspective the case for rotation of a Falklands microplate appears overwhelming: all of the geological evidence fits with it forming the 'missing' SE corner of the Karoo basin as originally proposed by Adie (1952a). All subsequent work, from detailed stratigraphical correlation to analyses of dyke composition and palaeomagnetism, is supportive of a rotational model. Nevertheless, it must be acknowledged that contrary views are held by colleagues who work mostly with offshore data that they consider provide no support for rotation and are compatible with extension of a fixed Falklands Plateau.

The hydrocarbons exploration programmes now active around the Falkland Islands are generating a huge amount of new data, but the majority are likely to remain commercially confidential for the foreseeable future. In time, any constraints provided by the offshore geology on rotation of a Falklands microplate will become clearer, but perhaps even then the question will only be resolved to the satisfaction of all parties by new and unequivocal palaeomagnetic results from the Falkland Islands dykes.

\section{Acknowledgements}

This paper is published by permission of the Director, Mineral Resources Department, Falkland Islands Government, and the Executive Director, British Geological Survey (NERC). Field work was facilitated by the staff of the Mineral Resources Department, and I am indebted to many colleagues for advice and discussion relating to aspects of 
Falkland Islands geology. In particular I should like to acknowledge the contributions of Phil Richards (BGS Edinburgh) with respect to the offshore geology, Don Aldiss (BGS Keyworth) with respect to the onshore geology and Adrian Rushton (The Natural History Museum, London) with respect to palaeontology. I am also grateful for the astute and helpful reviews provided by three referees: Ian Dalziel (The University of Texas at Austin, USA), John Marshall (University of Southampton, UK), Bryan Storey (University of Canterbury, Christchurch, NZ). Figures were drafted by Craig Woodward and the image plates were constructed by Brian McIntyre (both BGS Edinburgh) to whom my sincere thanks are due.

\section{References}

Adie, R. J. 1952a. The position of the Falkland Islands in a reconstruction of Gondwanaland. Geological Magazine, 89, 401-410.

Adie, R. J. 1952b. Representatives of the Gondwana System in the Falkland Islands. Symposium sur les series de Gondwana, XIXth International Geological Congress, Algiers, 1952. 385-392.

Aldiss, D. T. 1997. The Falkland Islands geological mapping project 1996-98. Falkland Islands Journal, 7 (1), 48-56.

Aldiss, D. T. \& Edwards, E. J. 1998. Geology of the Falkland Islands. Solid Geology 1:250 000. Two sheets, East and West. British Geological Survey for Falkland Islands Government.

Aldiss, D. T. \& Edwards, E. J. 1999. The Geology of the Falkland Islands. British Geological Survey Technical Report, WC/99/10. 135 pp. Available online at: http://nora.nerc.ac.uk/507542/

Alessandretti, L., Philipp, R. P., Chemale, F., Brückmann, M. P., Zvirtes, G., Matté, V. \& Ramos, V. A. 2013. Provenance, volcanic record, and tectonic setting of the Palaeozoic Ventania Fold Belt and the Claromecó Foreland Basin: Implications on sedimentation and volcanism along the southwest Gondwana margin. Journal of South American Earth Sciences, 47, 12-31.

Andersson, J. G. 1907. Contributions to the geology of the Falkland Islands. Wissenschaftliche Ergebnisse der Schwedischen Sudpolar-expedition 1901-1903, 3 (Lief. 2), 38 pp.

Baker, H. A. 1922. Geological investigations in the Falkland Islands. Proceedings of the Geological Society, London, 1093, 12-15

Baker, H. A. 1924. Final Report on Geological Investigations in the Falkland Islands, 1920-1922. Government Printer, Stanley. 38 pp, map, cross-section and 18 figures. 
Bangert, B., Stollhofen, H., Lorenz, V. \& Armstrong, R. 1999. The geochronology and significance of ash-fall tuffs in the glaciogenic Carboniferous-Permian Dwyka Group of Namibia and South Africa. Journal of African Earth Sciences, 29, 33-49.

Barker, P. F. 1999. Evidence for a volcanic rifted margin and oceanic crustal structure for the Falkland Plateau Basin. Journal of the Geological Society, London, 156, 889900 .

Bellosi, E. S. \& Jalfin, G. A. 1984. Litoestratigrafia y evolucion paleoambiental Neopaleozoica de las Islas Malvinas, Argentina. Noveno Congreso Geologico Argentino, S. C. de Bariloche, Actas V, 66-86.

Ben-Avraham, Z., Hartnady, C. J. H. \& Malan, J. A. 1993. Early tectonic extension between the Agulhas Bank and the Falkland Plateau due to the rotation of the Lafonia microplate. Earth and Planetary Science Letters, 117, 45-58.

Borrello, A. V. 1963. Sobre la geologia de las Islas Malvinas. Ministerio de Educación y Justica, Buenos Aires.

Bry, M., White, N., Singh, S., England, R. \& Trowell, C. 2004. Anatomy and formation of oblique continental collision: South Falkland basin. Tectonics, 23, TC4011, doi:10.1029/2002TC001482, 20 pp.

Burkhardt, F. \& Smith, S. (eds). 1987. The Correspondence of Charles Darwin 3 (1844 to 1846). Cambridge: Cambridge University Press.

Carvalho, M. G. P. de, 2006. Devonian trilobites from the Falkland Islands. Palaeontology, Vol. 49, 21-34.

Catuneanu, O., Hancox, P. J. \& Rubidge, B. S. 1998. Reciprocal flexural behaviour and contrasting stratigraphies: a new basin development model for the Karoo retroarc foreland system, South Africa. Basin Research, 10, 417-439.

Cawkell, M. 2001. The History of the Falkland Islands. Anthony Nelson, Oswestry. 189 pp.

Cingolani, C. A. \& Varela, R. 1976. Investigaciones geológicas y geochronológicas en el extremo sur de la isla Gran Malvina, sector do Cabo Belgrano (Cabo Meredith), Islas Malvinas. In: Actas del $6^{\circ}$ Congreso Geológico Argentino, Buenos Aires, 1, 457473.

Clarke, J. M. 1913. Fósseis Devonianos do Paraná. Monographia do Serviço Geológico y Mineralógico do Brasil, No 1, 353 pp.

Craddock, J. \& Thomas, R. 2011. Detrital zircon provenance ages of the "Dwyka Tillite" in South Africa and the Falkland Islands. Abstract, Geosynthesis, Cape Town, 33-34. 
Cramer, F. H. \& Cramer, M. D. 1972. Exclusive occurrence of chitinozoans and miospores in a shale of Devonian age from the Malvinas Islands. Revista de la Asociacion Paleontologica Argentina, 9, 220-222.

Curtis, M. L. \& Hyam, D. M. 1998. Late Palaeozoic to Mesozoic structural evolution of the Falkland Islands: a displaced segment of the Cape Fold Belt. Journal of the Geological Society, London, 155, 115-129.

Dalziel, I. W. D. \& Lawver, L. A. 2001. The lithospheric setting of the West Antarctic Ice sheet. In: Alley, R. B. \& Bindschadler, R. A. (eds) The West Antarctic Ice Sheet: Behaviour and Environment. Antarctic Research Series, American Geophysical Union, 77, 29-44.

Dalziel, I. W. D., Lawver, L. A., Norton, I. O., Gahagan, L. M. 2013. The Scotia Arc: Genesis, Evolution, Global Significance. Annual Review of Earth and Planetary Science, 41, 767-793.

Darwin, C. R. 1846. On the geology of the Falkland Islands. Quarterly Journal of the Geological Society of London, 2, 267-274.

Dawson, J. C. 1967. The geology of the Bluff Cove area, Falkland Islands. Unpublished M.Sc. thesis, University of California, Los Angeles.

de Wit, M. J. 1992. The Cape Fold Belt: A challenge for an integrated approach to inversion tectonics. In: de Wit, M J. \& Ransome, I. G. D. (eds) Inversion Tectonics of the Cape Fold Belt, Karoo and Cretaceous Basins of Southern Africa. A. A. Balkema, Rotterdam \& Brookfield, 3-12.

Duncan, R. A., Hooper, P. R., Rehacek, J., Marsh, J. S. \& Duncan, A. R. 1997. The timing and duration of the Karoo igneous event, southern Gondwana. Journal of Geophysical Research, 102, 18.127-18.138.

Du Toit, A. L. 1927. A geological comparison of South America with South Africa. Carnegie Institution, Washington. 158 pp.

Du Toit, A. L. 1937. Our Wandering Continents. Oliver \& Boyd, Edinburgh \& London, 366 pp.

Eagles, G. \& Vaughan, A. P. M. 2009. Gondwana breakup and plate kinematics: Business as usual. Geophysical Research Letters, 36, doi: 10.1029/2009GL037552.

Edgecombe, G. D. 1994. Calmoniid trilobites from the Devonian Fox Bay Formation, Falkland Islands: systematics and biogeography. New York State Museum Bulletin, Vol. 481, 55-68.

Edwards, E. J. 1997. A brief description of the geology of Beauchêne Island. Falkland Islands Journal, 7 (1), 40-47. 
Encarnación, J., Fleming, T. H., Elliot, D. H. \& Eales, H. V. 1996. Synchronous emplacement of Ferrar and Karoo dolerites and the early breakup of Gondwana. Geology, 24, 535-538.

Etheridge, R. 1885. Notes on the fossils collected by the Expedition. Report on the scientific results of the voyage of H.M.S. Challenger during the years 1873-76. Narrative - Vol. 1 (2 ${ }^{\text {nd }}$ Part), 892-894.

Frakes, L. A. \& Crowell, J. C. 1967. Facies and paleogeography of Late Paleozoic Diamictite, Falkland Islands. Geological Society of America Bulletin, 78, 37-58.

González, P. D., Tortello, M. F., Damborenea, S. E., Naipauer, M., Sato, A. M. \& Varela, R. 2012. Archaeocyaths from South America: review and a new record. Geological Journal, doi: 10.1002/gj.2415 (2013. 48, 114-125).

Gradstein, F. M., Ogg, J. G., Schmitz, M. D. \& Ogg, G. M. (eds). 2012. The Geologic Time Scale 2012. Elsevier, Oxford, Amsterdam \& Waltham MA.

Greenway, M. E. 1972. The geology of the Falkland Islands. British Antarctic Survey Scientific Reports, 76, 42 pp.

Gregory, J. W. 1929. The Geological History of the Atlantic Ocean. Quarterly Journal of the Geological Society, London, 85, Proceedings lxviii-cxxii.

Grunow, A. M., Dalziel, I. W. D. \& Kent, D. V. 1987. Ellsworth-Whitmore Mountains crustal block, western Antarctica: new paleomagnetic data and their tectonic significance. In: McKenzie, G. D. (ed) Gondwana Six: Structure, Tectonics and Geophysics. American Geophysical Union Monographs, 40, 161-172.

Hälbich, I. W. 1992. The Cape Fold Belt Orogeny: State of the art 1970's - 1980's. In: de Wit, M J. \& Ransome, I. G. D. (eds) Inversion Tectonics of the Cape Fold Belt, Karoo and Cretaceous Basins of Southern Africa. A. A. Balkema, Rotterdam \& Brookfield, 141-158.

Halle, T. G. 1911. On the geological structure and history of the Falkland Islands. Bulletin of the Geological Institution of the University of Uppsala, 11, 115-229.

Hodgkinson. R. 2002. Structural studies in the Falkland Islands, South Atlantic. Unpublished $\mathrm{PhD}$ thesis, University of Birmingham.

Horan, K. 2015. Falkland Islands (Islas Malvinas) in the Permo-Carboniferous. Springer Earth Systems Sciences. 174 pp.

Hunter, A. W., Rushton, A. W. A. \& Stone, P. 2014. Protasterid ophiuroid from the Early Devonian of the Fox Bay Formation, Falkland Islands: unravelling the missing fossil record of Upper Palaeozoic Asterozoans from Gondwana. In Kido, E., Waters, J. A., Ariunchimeg, Y. A., Sersmaa, G., Da Silva, A. C., Whalen, M., Suttner, T. J. \& Königshof, P. IGCP 596 \& IGCP 580 Joint Meeting and Field-Workshop International Symposium in Mongolia: Ulaanbaatar, Mongolia $5-18^{\text {th }}$ August 2014. 
Berichte des Institutes für Erdwissenschaften, Karl-Franzens-Universität Graz, Austria. 19, 27-28.

Hunter, M. A. \& Lomas, S. A. 2003. Reconstructing the Siluro-Devonian coastline of Gondwana: insights from the sedimentology of the Port Stephens Formation, Falkland Islands. Journal of the Geological Society, London, 160, 459-476.

Hyam, D. M. 1998. Structural evidence for the fit of the Falkland Islands in pre breakup Gondwana. Geoscientist, 8 (5), 4-7.

Hyam, D. M., Marshall, J. A. E. \& Sanderson, D. J. 1997. Carboniferous diamictite dykes in the Falkland Islands. Journal of African Earth Sciences, 25, 505-517.

Hyam, D. M., Marshall, J. A. E., Bull, J. M. \& Sanderson, D. J. 2000. The structural boundary between East and West Falkland: new evidence for movement history and lateral extent. Marine and Petroleum Geology, 17, 13-26.

Jacobs, J., Thomas, R. J., Armstrong, R. A. \& Henjes-Kunst, F. 1999. Age and thermal evolution of the Mesoproterozoic Cape Meredith Complex, West Falkland. Journal of the Geological Society, London, 156, 917-928.

Jalfin, G. A. \& Bellosi, E. S. 1983. Analisis estratigraphico de la Formación Bahia Choiseul, Permico de la Isla Soledad, Islas Malvinas - Republica Argentina. Revista Asociacion Geologica Argentina, 38, 248-262.

Keidel, J. 1916. La Geología de las Sierras de la Provincia de Buenos Aires y sus Relaciones con las Montañas de Sud Africa y los Andes. Annales del Ministerio de Agricultura de la Nación, Sección Geolgía, Mineralogía y Minería, 11 (3), 5-78.

Kimbell, G. S. \& Richards, P. C. 2008. The three-dimensional lithospheric structure of the Falkland Plateau region based on gravity modelling. Journal of the Geological Society, London, 165, 795-806.

Klemt, C. \& Jokat, W. 2015. The Crustal Structure of the Falkland Plateau from Wide-angle Seismic Data. American Geophysical Union Abstract T51F-2987. Fall Meeting 2015.

Lawrence, S. R., Johnson, M., Tubb, S. R \& Marshallsea, S. J. 1999. Tectonostratigraphic evolution of the North Falkland region. In: Cameron, N. R., Bate, R. H. \& Clure, V. S. (eds) The Oil and Gas Habitats of the South Atlantic. Geological Society, London, Special Publications, 153, 409-424.

Limarino, C. O., Massabie, A., Rossello, E., López Gamundi, O., Page, R. \& Jalfin, G. 1999. El Palaeozoico de Ventania, Patagonia e Islas Malvinas. In: Caminos R. (ed.) Geología Argentina. Instituto de Geología y Recursos Minerales, Buenos Aires, Anales No 29, 319-347 (Área de las Islas Malvinas, 337-341).

Lohr, T. \& Underhill, J. R. 2015. Role of rift transaction and punctuated subsidence in the development of the North Falkland Basin. Petroleum Geoscience, 21, 85-110. 
Lorenzo, J. M. \& Mutter, J. C. 1988. Seismic stratigraphy and tectonic evolution of the Falkland/Malvinas Plateau. Revista Brasileira de Geosciencias, 18, 191-200.

Macdonald, D., Gomez-Perez, I., Franzese, J., Spalletti, L., Lawver, L., Gahagan, L. Dalziel, I., Thomas, C., Trewin, N., Hole, M. \& Paton, D. 2003. Mesozoic break-up of SW Gondwana: implications for regional hydrocarbon potential of the southern South Atlantic. Marine and Petroleum Geology, 20, 287-308.

Macphail, M. \& Cantrill, D. J. 2006. Age and implications of the Forest Bed, Falkland Islands, southwest Atlantic Ocean: evidence from fossil pollen and spores.

Palaeogeography, Palaeoclimatology, Palaeoecology, 240, 602-629.

Maisey, J. G., Borghi, L. \& Carvalho, M. G. P. de. 2002. Lower Devonian fish remains from the Falkland Islands. Journal of Vertebrate Paleontology, 22, 708-711.

Marshall, J. E. A. 1994a. The Falkland Islands: a key element in Gondwana palaeogeography. Tectonics, 13, 499-514.

Marshall, J. E. A. 1994b. The Falkland Islands and the early fragmentation of Gondwana: implications for hydrocarbon exploration in the Falkland Plateau. Marine and Petroleum Geology, 11, 631-636.

Marshall, J. E. A. 2016 (in press). Palynological calibration of Devonian events at near-polar palaeolatitudes in the Falkland Islands, South America. In: Becker, R. T., Königshof, P. \& Brett, C. (eds) Devonian Climate, Sea Level and Evolutionary Events. Geological Society, London, Special Publications, 423.

Martin, A. K. 2007. Gondwana breakup via double-saloon-door rifting and seafloor spreading in a backarc basin during subduction rollback. Tectonophysics, 445, 245272.

Martin, A. K., Hartnady, C. H. J. H. \& Gooodland, S. W. 1981. A revised fit of South America and South Central Africa. Earth and Planetary Science Letters, 54, 293-305.

Meadows, N. S. 1999. Basin evolution and sedimentary fill in the Palaeozoic sequences of the Falkland Islands. In: Cameron, N. R., Bate, R. H. \& Clure, V. S. (eds) The Oil and Gas Habitats of the South Atlantic. Geological Society, London, Special Publications, 153, 445-464.

Mendía J. E., Anselmi, G. \& Negro, C. 2008. Las Islas Malvinas. In: Sitios de Interés Geológico de la República Argentina, Anales 46, II-Sur, edited by Comisión Sitios de Interés Geológico de la República Argentina, 875-889. Buenos Aires: Instituto de Geología y Recursos Minerales, Servicio Geológico Minero Argentino.

Milani, E. J. \& de Wit, M. J. 2008. Correlations between the classic Parana and CapeKaroo sequences of South America and southern Africa and their basin infills flanking the Gonwanides: Du Toit revisited. In: Pankhurst, R. J., Trouw, R. A. J., Brito Neves, B. B. \& De Wit, M. J. (eds) West Gondwana: Pre-Cenozoic Correlations across the South Atlantic Region. Geological Society, London, Special Publications, 294, 319-342. 
Mitchell, C., Ellam, R. M. \& Cox, K. G. 1999. Mesozoic dolerite dykes of the Falkland Islands: petrology, petrogenesis and implications for geochemical provinciality in Gondwanaland low-Ti basaltic rocks. Journal of the Geological Society, London, 156, 901-916.

Mitchell, C., Taylor, G. K., Cox, K. G. \& Shaw, J. 1986. Are the Falkland Islands a rotated microplate? Nature, 319, 131-134.

Mitchell-Thomé, R. C. 1970. Geology of the South Atlantic Islands. Gebrüder Borntraeger, Berlin \& Stuttgart. 306-335.

Morris, J. \& Sharpe, D. 1846. Description of eight species of brachiopodous shells from the Palaeozoic rocks of the Falkland Islands. Quarterly Journal of the Geological Society of London, Vol. 2, 274-278.

Mussett, A. E. \& Taylor, G. K. 1994. ${ }^{40} \mathrm{Ar}^{-39} \mathrm{Ar}$ ages for dykes from the Falkland Islands with implications for the break up of southern Gondwanaland. Journal of the Geological Society, London, 151, 79-81.

Newman, R. P. 1995. American Intransigence: The Rejection of Continental Drift in the Great Debates of the 1920s. Earth Sciences History, 14, 62-83.

Newton, E. T. 1906. Notes on fossils from the Falkland Islands brought home by the Scottish National Antarctic Expedition in 1904. Proceedings of the Royal Physical Society of Edinburgh, 16, 248-257.

Oreskes, N. 1999. The Rejection of Continental Drift. Oxford University Press, New York and Oxford, xi + 420 pp.

Permanent Committee on Geographical Names, The. 2006. The Toponymy of the Falkland Islands as Recorded on Maps and in Gazetteers. www.pcgn.org.uk/Falkland\%20Islands-July2006.

Rabinowitz, P. D. \& LaBrecque, J. L. 1979. The Mesozoic South Atlantic Ocean and evolution of its continental margins. Journal of Geophysical Research, 84, 59736002.

Ramos, V.A. 2008. Patagonia: A Palaeozoic continent adrift? Journal of South American Earth Sciences, 26, 235-251.

Randall, D. E. \& Mac Niocaill, C. 2004.Cambrian palaeomagnetic data confirm a Natal Embayment location for the Ellsworth-Whitmore Mountains, Antarctica, in Gondwana reconstructions. Geophysical Journal International, 157, 105-116.

Rex, D. C. \& Tanner, P. W. G. 1982. Precambrian age for gneisses at Cape Meredith in the Falkland Islands. In: Craddock, C. (ed.) Antarctic Geoscience. University of Wisconsin Press, International Union of Geological Sciences, Series B, 4, 107-108. 
Richards, P. C. \& Fannin, N.G.T. 1997. Geology of the North Falklands Basin. Journal of Petroleum Geology, 20, 165-183.

Richards, P. C. \& Hillier, B. V. 2000a. Post-drilling analysis of the North Falklands Basin - Part 1: tectono-stratigraphic framework. Journal of Petroleum Geology, 23, 253-272.

Richards, P. C. \& Hillier, B. V. 2000b. Post-drilling analysis of the North Falklands Basin - Part 2: petroleum systems and future prospects. Journal of Petroleum Geology, 23, 273-292.

Richards, P., Duncan, I., Phipps, C., Pickering, G., Grzywacz, J. Hoult, R. \& Merritt, J. 2006. Exploring for fan and delta sandstones in the offshore Falklands basins. Journal of Petroleum Geology, 29, 199-214.

Richards, P. C., Gatliff, R. W., Quinn, M. F., Williamson, J. P. \& Fannin, N. G. T. 1996. The geological evolution of the Falkland Islands continental shelf. In: Storey, B. C., King, E. C. \& Livermore, R. A. (eds) Weddell Sea Tectonics and Gondwana Break-up, Geological Society, London, Special Publications, 108, 105-128.

Richards, P. C., Stone, P., Kimbell, G. S., McIntosh, W. C. \& Phillips, E. R. 2013. Mesozoic magmatism in the Falkland Islands (South Atlantic) and their offshore sedimentary basins. Journal of Petroleum Geology. 36, 61-74.

Riley, T. R. \& Knight, K. B. 2001. Age of pre-break-up Gondwana magmatism: a review. Antarctic Science, 13, 99-110.

Rocca, M. C. L. \& Báez Presser, J. L. 2015. A possible new very large impact structure in Malvinas Islands. Historia Natural, 5, 121-133.

Rushton, A.W.A. \& Stone. P. 2011. Two notable new fossil finds in East Falkland: a 'starfish' and a large trilobite. Falkland Islands Journal, 9 (5), 5-13.

Scasso, R. A. \& Mendia, J. E. 1985. Rasgos estratigraficos y paleoambiantalesdel paleozoico de las Islas Malvinas. Revista Asociación Geológica Argentina, 40, 26-50.

Seward, A. C. \& Walton, J. 1923. On a collection of fossil plants from the Falkland Islands. Journal of the Geological Society, London, 79, 313-333.

Sharpe, D. \& Salter, J. W. 1856. Description of Palaeozoic fossils from South Africa. Transactions of the Geological Society of London, Series 2, 7, 203-225.

Simões, M. G., Quaglio, F., Warren, L. V., Anelli, L. E., Stone, P., Riccomini, C., Grohmann, C. H. \& Chamani, M. A. C. 2012. Permian non-marine bivalves of the Falkland Islands and their palaeoenvironmental significance. Alcheringa, 36, 543-554.

Smalley, R., Kendrick, E., Bevis, M. G., Dalziel, I. W. D., Taylor, F., Lauria, E., Barriga, R., Casassa, G., Olivero, E. \& Piana, E. 2003. Geodetic determination of relative plate motion and crustal deformation across the Scotia-South America plate 
boundary in eastern Tierra del Fuego. Geochemistry, Geophysics, Geosystems, 4 (9), 19 pp.

Stone, P. 2011. Borehole core recovered from the late Carboniferous to early Permian Fitzroy Tillite and Port Sussex formations, Falkland Islands: geological background and sample details. British Geological Survey Open Report, OR/11/028. 19pp. Available online at: http://nora.nerc.ac.uk/14415/

Stone, P. 2013. Mesozoic dyke swarms of the Falkland Islands (South Atlantic). British Geological Survey Open Report, OR/13/26. 27 pp. Available online at: http://nora.nerc.ac.uk/502936/

Stone, P. 2014. Recent contributions on Falkland Islands bedrock geology, with an inventory of representative lithostratigraphical specimens held by the British Geological Survey. British Geological Survey Open Report, OR/14/040. 43 pp. Available online at: http://nora.nerc.ac.uk/507998/

Stone, P. 2015. Geological exploration of South Atlantic islands and its contributions to the continental drift debate of the early $20^{\text {th }}$ century. Proceedings of the Geologists' Association, 126, 266-281.

Stone, P. \& Faithfull, J. 2013. The mineral prospecting expeditions to the South Atlantic islands and Antarctic Peninsula region made by the Scottish geologist David Ferguson, 1912-1914. Scottish Journal of Geology. 49, 59-77.

Stone, P. \& Horan, K. 2016. Early Permian climate change in the Falkland Islands. Geology Today, 32, 107-114.

Stone, P. \& Rushton, A. W. A. 2012. The pedigree and influence of fossil collections from the Falkland Islands: from Charles Darwin to continental drift. Proceedings of the Geologists' Association, 123, 520-532.

Stone, P. \& Rushton, A. W. A. 2013. Charles Darwin, Bartholomew Sulivan and the geology of the Falkland Islands: unfinished business from an asymmetric partnership. Earth Sciences History, 32, 156-185.

Stone, P. \& Thomson, M. R. A. 2005. Archaeocyathan limestone blocks of likely Antarctic origin in Gondwanan tillite from the Falkland Islands. In: Vaughan, A. P. M., Leat, P. T. \& Pankhurst, R. J. (eds) Terrane Processes at the Margins of Gondwana. Geological Society, London, Special Publications, 246, 347-357.

Stone, P., Kimbell, G. S. \& Richards, P. C. 2009. Rotation of the Falklands microplate reassessed after recognition of discrete Jurassic and Cretaceous dyke swarms. Petroleum Geoscience, 15, 279-287.

Stone, P., Richards, P. C., Kimbell, G. S., Esser, R. P. \& Reeves, D. 2008. Cretaceous dykes discovered in the Falkland Islands: implications for regional tectonics. Journal of the Geological Society, London, 165, 1-4. 
Stone, P., Thomson, M. R. A. \& Rushton, A. W. A. 2012 (for 2011). An Early Cambrian archaeocyath-trilobite fauna in limestone erratics from the Upper Carboniferous Fitzroy Tillite Formation, Falkland Islands. Earth and Environmental Science Transactions of the Royal Society of Edinburgh. 102, 201-225.

Storey, B. C., Curtis, M. L., Ferris, J. K., Hunter, M .A. \& Livermore, R. A. 1999. Reconstruction and break-out model for the Falkland Islands within Gondwana. Journal of African Earth Sciences, 29, 153-163.

Storey, B. C., Vaughan, A. P. M. \& Riley, T.R. 2013. The links between large igneous provinces, continental break-up and environmental change: evidence reviewed form Antarctica. Earth and Environmental Science Transactions of the Royal Society of Edinburgh. 104, 17-30.

Suess, E. 1909. The Face of the Earth. (English translation of Das Antlitz der Erde by H. B. C. Sollas), 4. The Clarendon Press, Oxford. 673 pp.

Tankard, A., Welsink, H., Aukes, P., Newton, R. \& Stettler, E. 2009. Tectonic evolution of the Cape and Karoo basins of South Africa. Marine and Petroleum Geology, 26, 1379-1412.

Tankard, A., Welsink, H., Aukes, P., Newton, R. \& Stettler, E. 2012. Geodynamic interpretation of the Cape and Karoo basins, South Africa. In: Roberts, D. G. \& Bally, A. W. (eds) Phanerozioc passive margins, Cratonic basins and Global Tectonic Maps. Elsevier. 869-945.

Tarney, J. 1977. Petrology, Mineralogy, and Geochemistry of the Falkland Plateau Basement Rocks, Site 330, Deep Sea Drilling Project. doi: 10.2973/dsdp.proc.36.123.1977.

Taylor, G. K. \& Shaw, J. 1989. The Falkland Islands: New palaeomagnetic data and their origin as a displaced terrane from southern Africa. In: Hillhouse, J. W. (ed.) Deep structure and past kinematics of accreted terranes (IUGGVolume 5). AGU Geophysical Monographs, 50, 59-72.

Thistlewood, L. \& Randall, D. 1998. Palaeomagnetic studies of West Gondwanan microplates. Journal of African Earth Sciences, 27 (1A: Gondwana 10: Event Stratigraphies of Gondwana (abstracts)), 227.

Thistlewood, L., Leat, P. T., Millar, I. L., Storey, B. C. \& Vaughan, A. P. M. 1997. Basement geology and Palaeozoic-Mesozoic mafic dykes from the Cape Meredith Complex, Falkland Islands: a record of repeated intracontinental extension. Geological Magazine, 134, 355-367.

Thomas, R. J., Henjes-Kunst, F. \& Jacobs, J. 1998. Pre-lamprophyre mafic dykes of the Cape Meredith Complex, West Falkland. Geological Magazine, 135, 495-500.

Thomas, R. J., Jacobs, J. \& Weber, K. 1997. Geology of the Mesoproterozoic Cape Meredith Complex, West Falkland. In: Ricci, C.A. (ed.) The Antarctic Region: Geological Evolution and Processes, Terra Antarctica Publication, Siena, 21-30. 
Thomson, K. 1998. When did the Falklands rotate? Marine and Petroleum Geology, 15, 723-736.

Thomson, K., Hegarty, K. A., Marshallsea, S. J. \& Green, P. F. 2002. Thermal and tectonic evolution of the Falkland Islands: implications for hydrocarbon exploration in the adjacent offshore region. Marine and Petroleum Geology, 19, 95-116.

Tillyard, R.J. 1928. A Permian fossil damselfly wing from the Falkland Islands. Transactions of the Entomological Society of London, 76, 55-63.

Trewin, N. H. 2000. The ichnogenus Undichna, with examples from the Permian of the Falkland Islands. Palaeontology, 43, 979-997.

Trewin, N. H., Macdonald, D. I. M. \& Thomas, C. G. C. 2002. Stratigraphy and sedimentology of the Permian of the Falkland Islands: lithostratigraphic and palaeoenvironmental links with South Africa. Journal of the Geological Society, London, 159, 5-19.

Turner, J. C. M. 1980. Islas Malvinas. Segundo Simposio de Geología Regional Argentina, Cordoba, 2, 1503-1527.

Webers, G. F., Craddock, C. \& Splettstoesser J. F. 1992. Geological history of the Ellsworth Mountains, West Antarctica. In: Webers, G. F., Craddock, C. \& Splettstoesser J. F. (eds) Geology and Paleontology of the Ellsworth Mountains, West Antarctica. Geological Society of America Memoir, 170, 1-8.

Wegener, A. 1922. Die Ehtstehung der Kontinente und Ozeane (3rd edition). Friedrich Vieweg \& Sohn, Braunschweig. English translation by Skerl, J. G. A. Published as The Origin of Continents and Oceans by Methuen, London. 1924.

Wegener, A. 1929. Die Ehtstehung der Kontinente und Ozeane (4th edition). Friedrich Vieweg \& Sohn, Braunschweig. English translation by Biram, J. Published as The Origin of Continents and Oceans in the USA by Dover Publications Inc. and in the UK by Methuen, London. 1966 and 1967. 


\section{Figure and Table Captions}

Figure 1.

The regional setting of the Falkland Islands in the South Atlantic Ocean:

a. The Falkland Islands in relation to southern South America and the North Scotia Ridge.

b. The Falkland Islands and the locations of their surrounding Mesozoic to Palaeogene sedimentary basins.

Figure 2.

An outline of the onshore, bedrock geology of the Falkland Islands

(lithostratigraphical outcrop excluding dykes) after Aldiss \& Edwards (1998).

Figure 3.

A summary of the geological history of the Falkland Islands and their offshore environs. For the onshore lithostratigraphy the stratigraphical thicknesses shown are for East Falkland; the West Falkland succession is significantly thinner. For details of representative lithostratigraphical specimens held by the British Geological Survey see Stone (2014).

Figure 4.

A representation of the Gondwana continental configuration in the Early Jurassic, immediately prior to the commencement of its break-up, simplified after Dalziel et al. (2013, fig. 3) and with igneous provinces from Storey et al. (2013, fig. 1).

Figure 5.

Fossils from the Falkland Islands: a-e, examples of the Devonian Malvinokaffric fauna from the Fox Bay Formation; f, Cambrian archeaocyaths from a limestone clast in the Permian Fitzroy Tillite Formation; g, a Permian bivalve from the Brenton Loch Formation.

a. Brachiopods. The larger shells are Schellwienella sulivani; they are internal moulds of the pedicle valve and show fine radial ribbing. The smaller shells are Australocoelia palmata; the paler specimen (on the left) is an internal mould of a pedicle valve, but there are fragments of brachial valves and 
external moulds, all of which show the coarse ribbing. Fox Bay, West Falkland. BGS image P100659.

b. Trilobite. An oblique anterior view of a cephalon (head-shield) of the Homalonotid Burmeisteria herschelii with part of the thorax attached. The animal's right eye is elevated, well seen on the left side of the figure, but the left eye has broken off. Pebble Island, West Falkland. BGS image P618374.

c. Brachiopods and a trilobite. A variety of internal and external moulds of the small, coarsely-ribbed Australocoelia palmata. The much larger shell is the pedicle valve of Australospirifer hawkinsii, preserved as an internal mould. Note also the small pygidium (tail-piece, arrowed) of a calmoniid trilobite. Saddle Quarry, West Falkland. BGS image P549540 (detail).

d. Starfish-like ophiuroid or 'brittle-star' preserved as a natural impression (an external mould) of the under-side. Fish Creek, East Falkland. BGS image P727089.

e. A gastropod with a large part of the shell broken away, showing a natural mould of the body-chamber. The upper part retains the shell-material and is encrusted by a bryozoan colony. Pebble Island, West Falkland. BGS image P511902.

f. Archaeocyaths. A thin section from a limestone clast showing several species including Metacyathellus lairdi (left and centre), scattered ?Erismacoscinus sp., and Spirocyathella cf. cooperi (bottom left). Hill Cove, West Falkland. BGS image P537735.

g. Conjoined shells of a Permian bivalve, Palaeanodonta sp. aff. P. dubia, showing the growth-lines. Rory’s Creek, East Falkland. BGS image P573118.

Figure 6.

The E-W mountainous ridge of central East Falkland created by the outcrop of the Port Stanley Formation.

a. Quartzite crags at Tumbledown, overlooking Port Stanley. The figure standing on the summit provides a sense of scale. BGS image P587736.

b. The Wickham Heights and Mount Usborne, at $705 \mathrm{~m}$ the highest point in the Falkland Islands, seen from Darwin. The subdued foreground topography is characteristic of the Lafonia Group outcrop. BGS image P696257. 
Figure 7.

Examples of characteristic Falkland Islands lithologies.

a. Typical exposure of the hard quartzites of the Port Stanley Formation, seen here looking east towards Stanley at the eastern end of the Wickham Heights, East Falkland. BGS image P696221.

b. Tabular cross bedding, a widespread feature in the Port Stanley Formation, seen on the Cape Pembroke promontory to the east of Stanley, East Falkland.

c. Quartzite and granitic clasts in diamictite of the Fitzroy Tillite Formation near Hill Cove, on the north coast of the West Falkland mainland to the north of Mount Adam.

d. A Fitzroy Tillite Formation (diamictite) section carrying a sub-horizontal fabric seen near Hill Cove, on the north coast of the West Falkland mainland to the north of Mount Adam. The hammer rests against a cobble of archaeocyathan limestone eroded from the cliff.

e. Thinly interbedded sandstone and mudstone of the Brenton Loch Formation at Salinas Beach, 3km west of Darwin, East Falkland. BGS image P696250.

f. Ripple-bedded sandstone of the Bay of Harbours Formation at New Haven, 20 km NW of Darwin, East Falkland. BGS image P696250.

Figure 8.

Representative onshore cross-sections illustrating the overall style of geological structure in the Falkland Islands.

Figure 9.

Examples of geological structure and dyke intrusion in East Falkland.

a. Large asymmetrical anticline (viewed towards the west) in Port Stanley Formation quartzite at Wall Mountain, $15 \mathrm{~km}$ west of Stanley.

b. Asymmetrical fold pair (viewed towards the east) in Port Stanley Formation quartzite at Wall Mountain, $15 \mathrm{~km}$ west of Stanley.

c. Penetrative slaty cleavage (dip is towards the north) developed in thinly interbedded sandstone, mudstone and diamictite in the uppermost part of the Fitzroy Tillite Formation near Fitzroy.

d. Localised fold and thrust development (N-verging) in sandstone of the Bay of Harbours Formation at Bodie Creek Bridge, 4 km SW of Goose Green. 
e. Fold and thrust development (S-verging) in mudstone of the Black Rock Member, Port Sussex Formation, at L’Antioja River, 27 km east of Darwin.

f. Early Cretaceous dolerite dyke cutting steeply inclined beds of Port Stanley Formation quartzite at Pony’s Pass Quarry, 7 km west of Stanley.

Figure 10.

Linear aeromagnetic anomalies interpreted as arising from dolerite dykes, showing the location of the analysed and dated outcrops. Note that the aeromagnetic survey covered only the two main islands and extended neither to the western promontories of West Falkland, nor to the smaller offshore islands. The survey comprised N-S flight lines at a typical spacing of $500 \mathrm{~m}$, with E-W tie lines at a spacing of $5 \mathrm{~km}$; the flying height was $120 \mathrm{~m}$ above ground surface. Extent of the Cape Orford dyke swarm after Aldiss \& Edwards (1999, fig.3.1).

Figure 11.

Variation diagrams for selected major oxides and trace elements (plotted against $\mathrm{MgO})$ that illustrate the contrasting compositions of the different dyke swarms.

Figure 12.

Two early solutions to the problem of the Falkland Islands' apparently misplaced geology:

a. The early attempt by Du Toit $(1927,1937)$ to align the main Falkland Islands structures with those of Ventania (Argentina) and Cape Province (South Africa).

b. The radical solution proposed by Adie (1952a) in which the islands are rotated anticlockwise through $180^{\circ}$ ( $30^{\circ}$ for opening of the South Atlantic and $150^{\circ}$ for pre-Atlantic rotation) to an original position adjacent to the SE coast of South Africa, where they form the 'missing' SE corner of the Karoo Basin.. Du Toit's Gondwana reconstruction shows the 'Limit of Mesosaurus', the shortlegged terrestrial reptile whose Permian palaeogeographical distribution influenced early views of Gondwana. My colleague D. Aldiss recalls (pers. comm. August 2015) attending a lecture by Adie in the 1970s during which he predicted the eventual discovery of Mesosaurus in the Falkland Islands. So far this has not happened. 


\section{Figure 13.}

Representative cross-sections of two of the Mesozoic to Palaeogene sedimentary basins in the Falkland Islands offshore zone.

a. The northern part of the North Falkland Basin, developed from Richards \& Fannin (1997) and Richards \& Hillier (2000a \& b).

b. The South Falkland Basin, after Richards et al. (1996) and Bry et al. (2004).

\section{Table 1.}

The broad lithostratigraphical correlation between the Falkland Islands (West

Falkland and Lafonia Groups) and South Africa (Cape and Karoo Supergroups). 


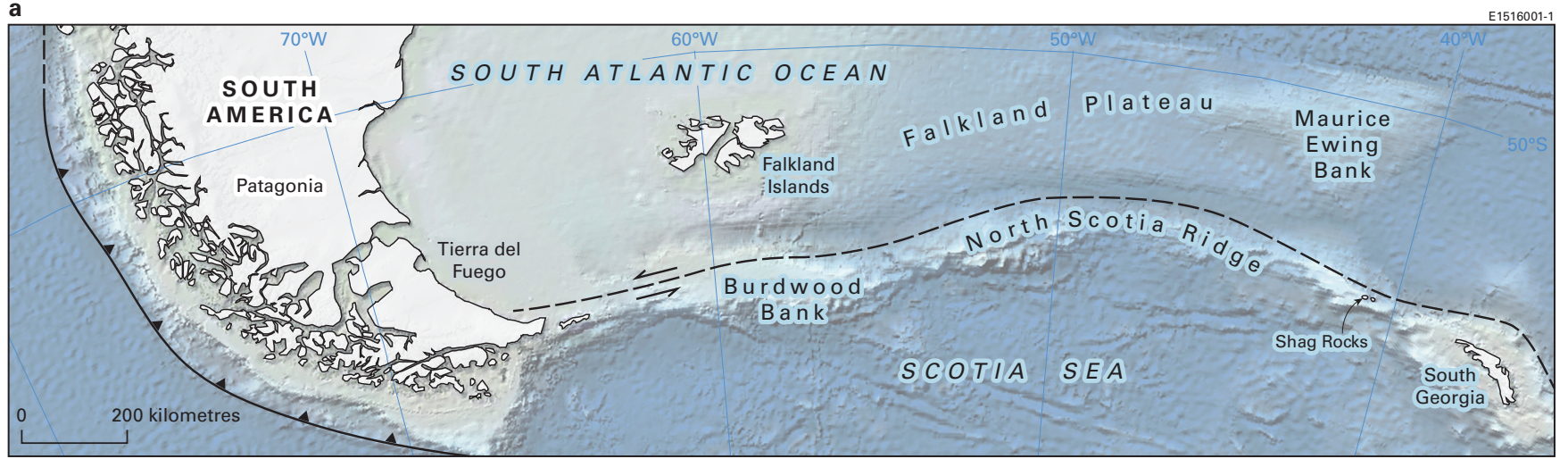

- - - - Transform fault $\quad$ _ Subduction zone

b

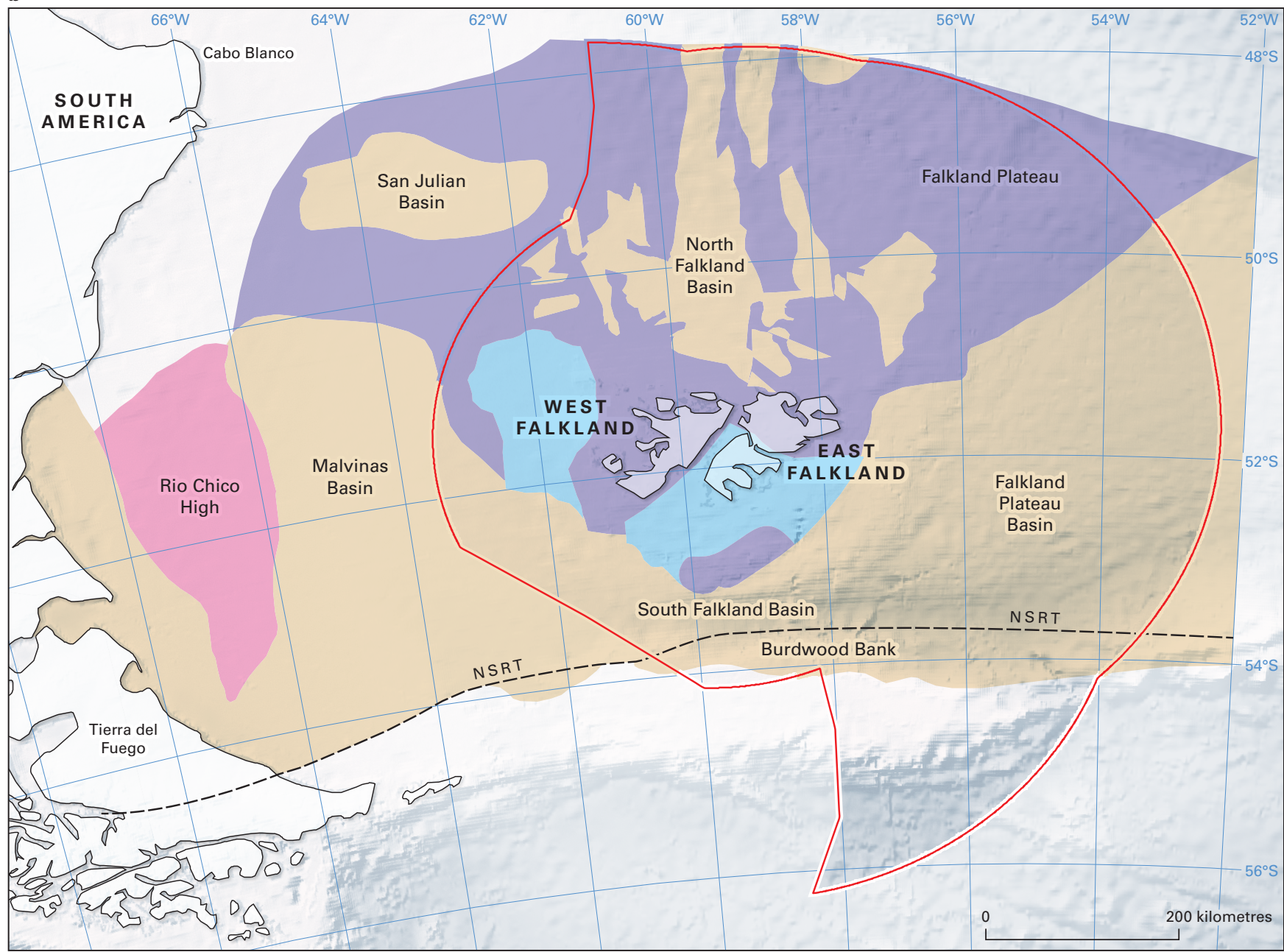

Possible extent of Cretaceous Palaeogene basins

Siluro-Devonian rocks

Permo-Carboniferous (and Triassic?) rocks (= Lafonia Group) (=West Falkland Group

Jurassic volcanic rocks?

NS RT

Boundary of the Falkland Islands offshore exploration zone 


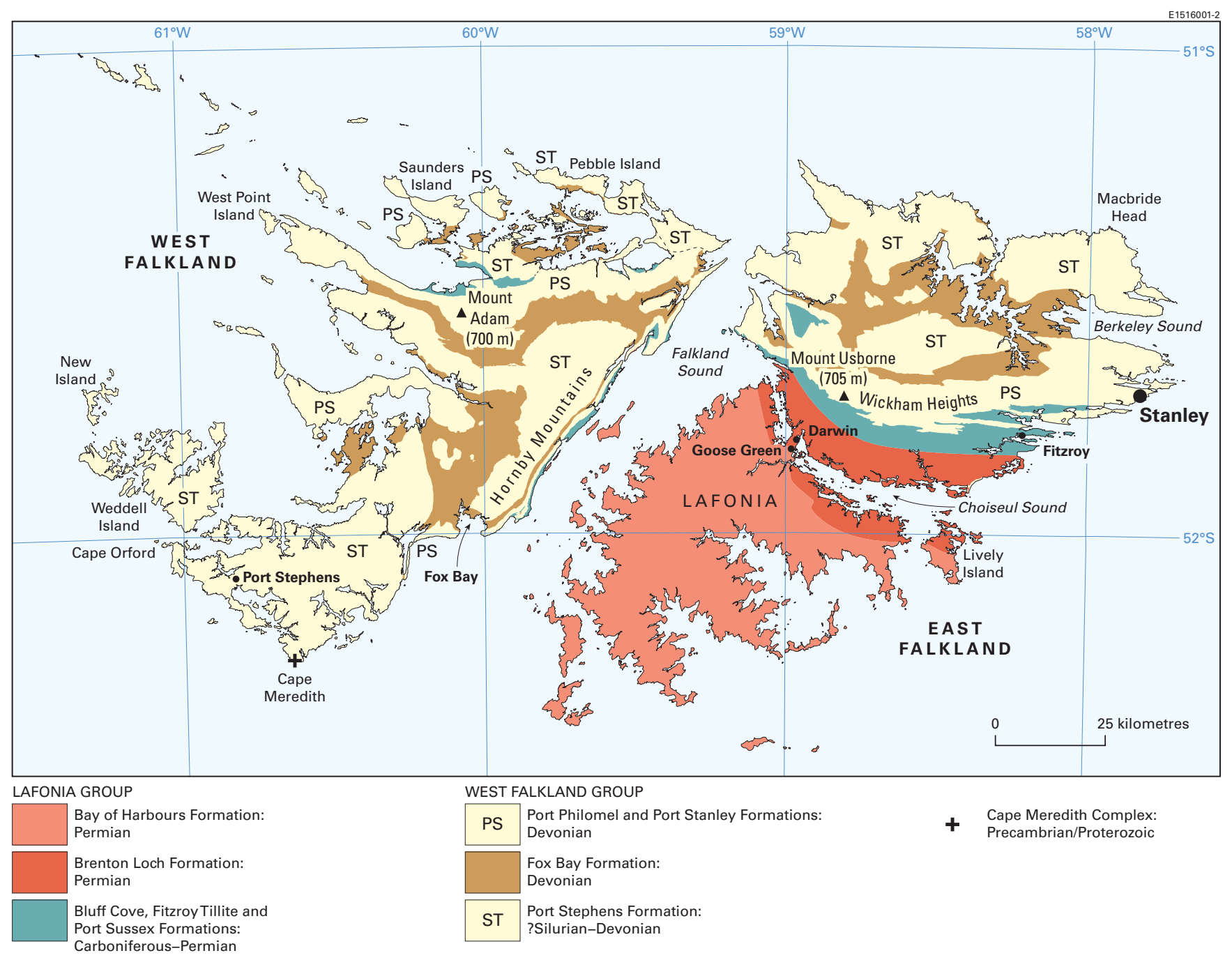




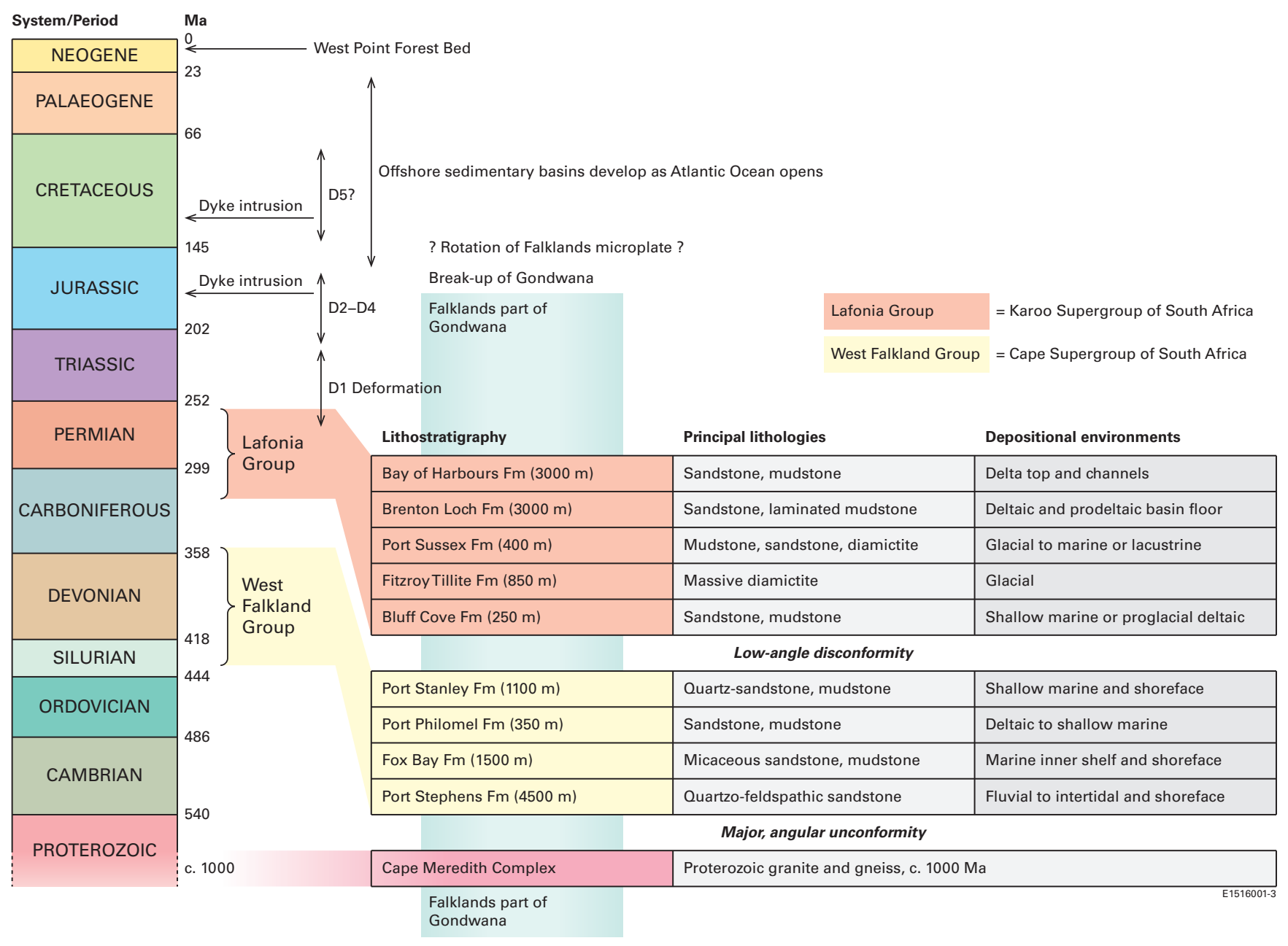




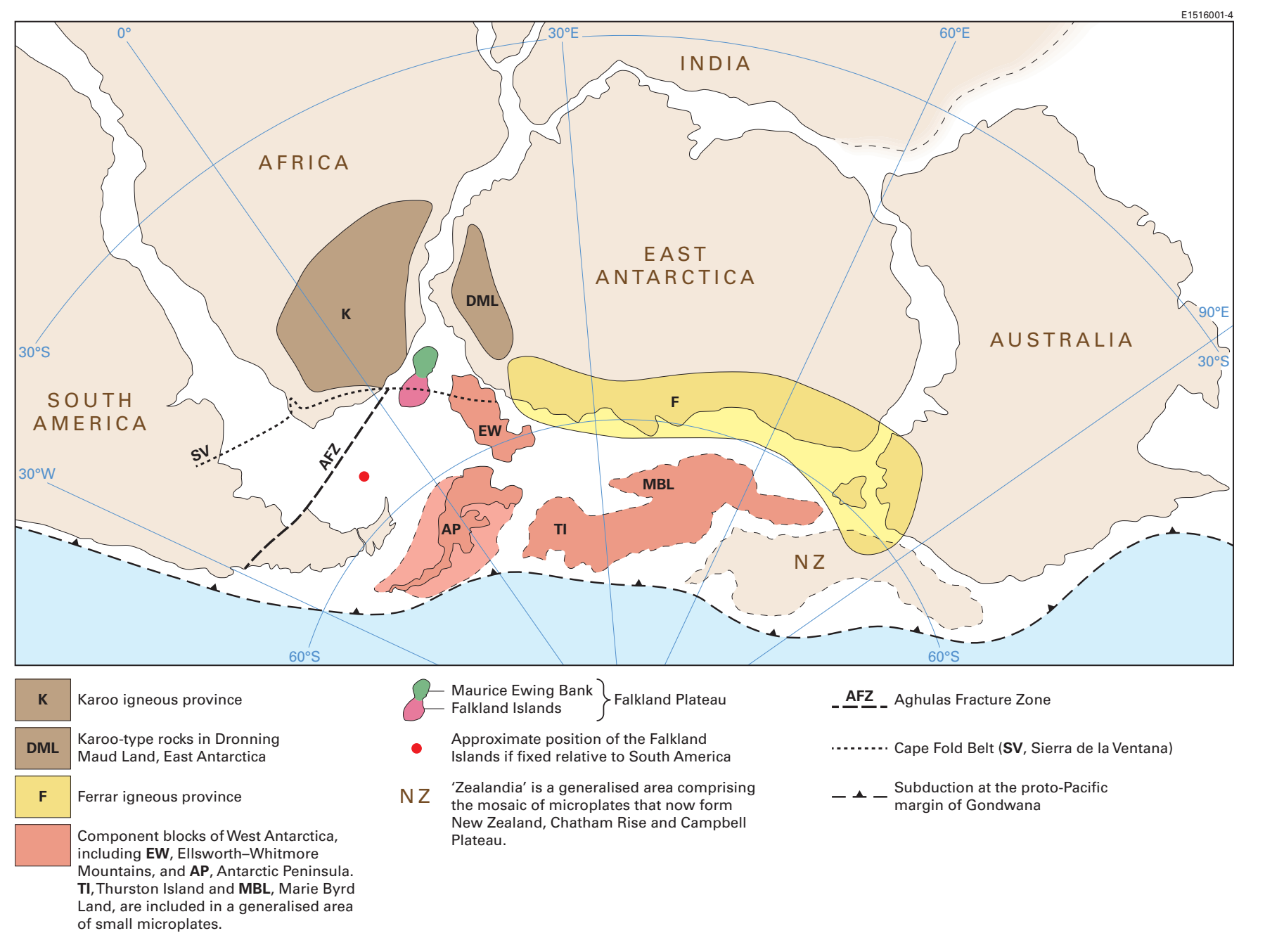



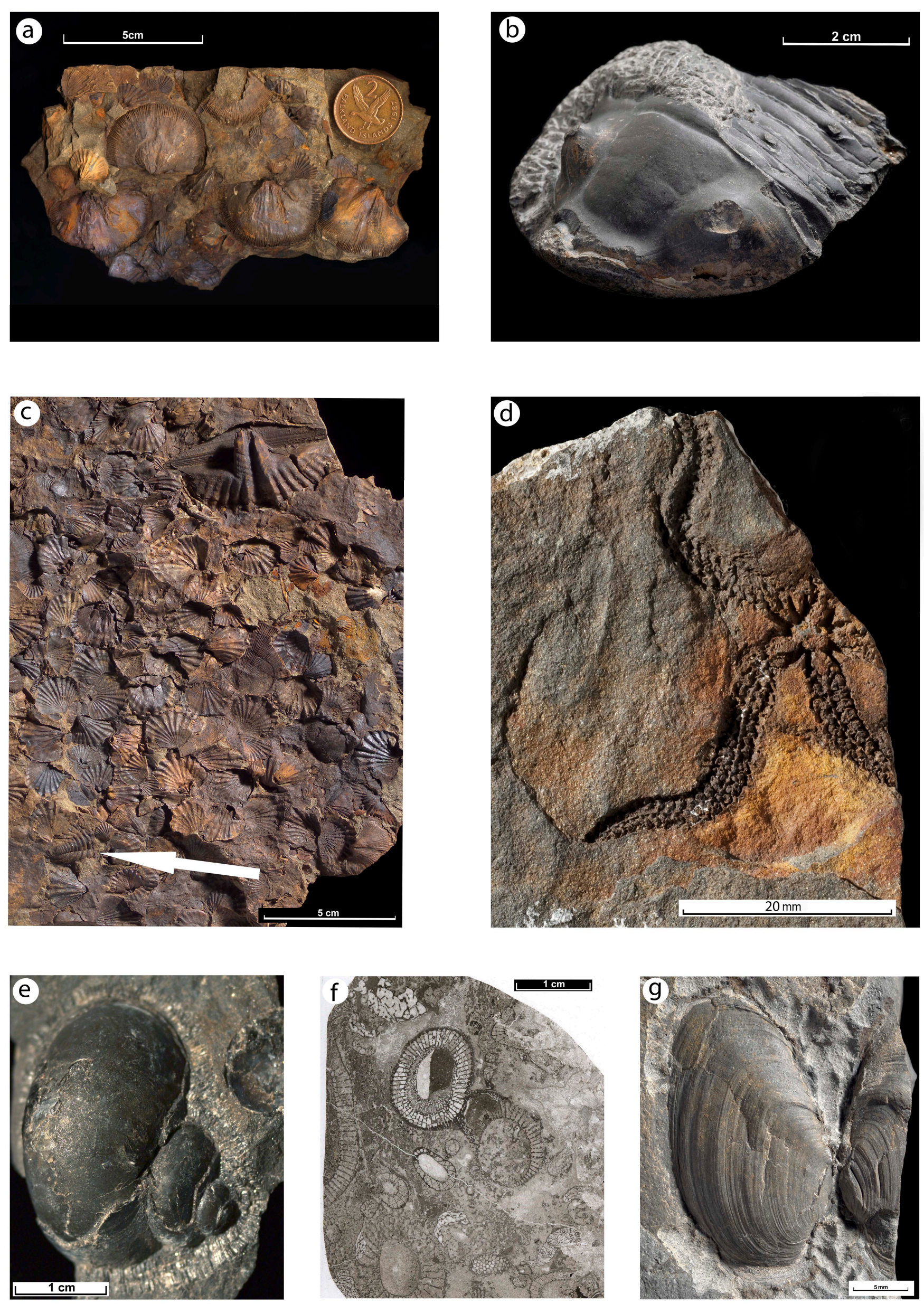


\section{a}

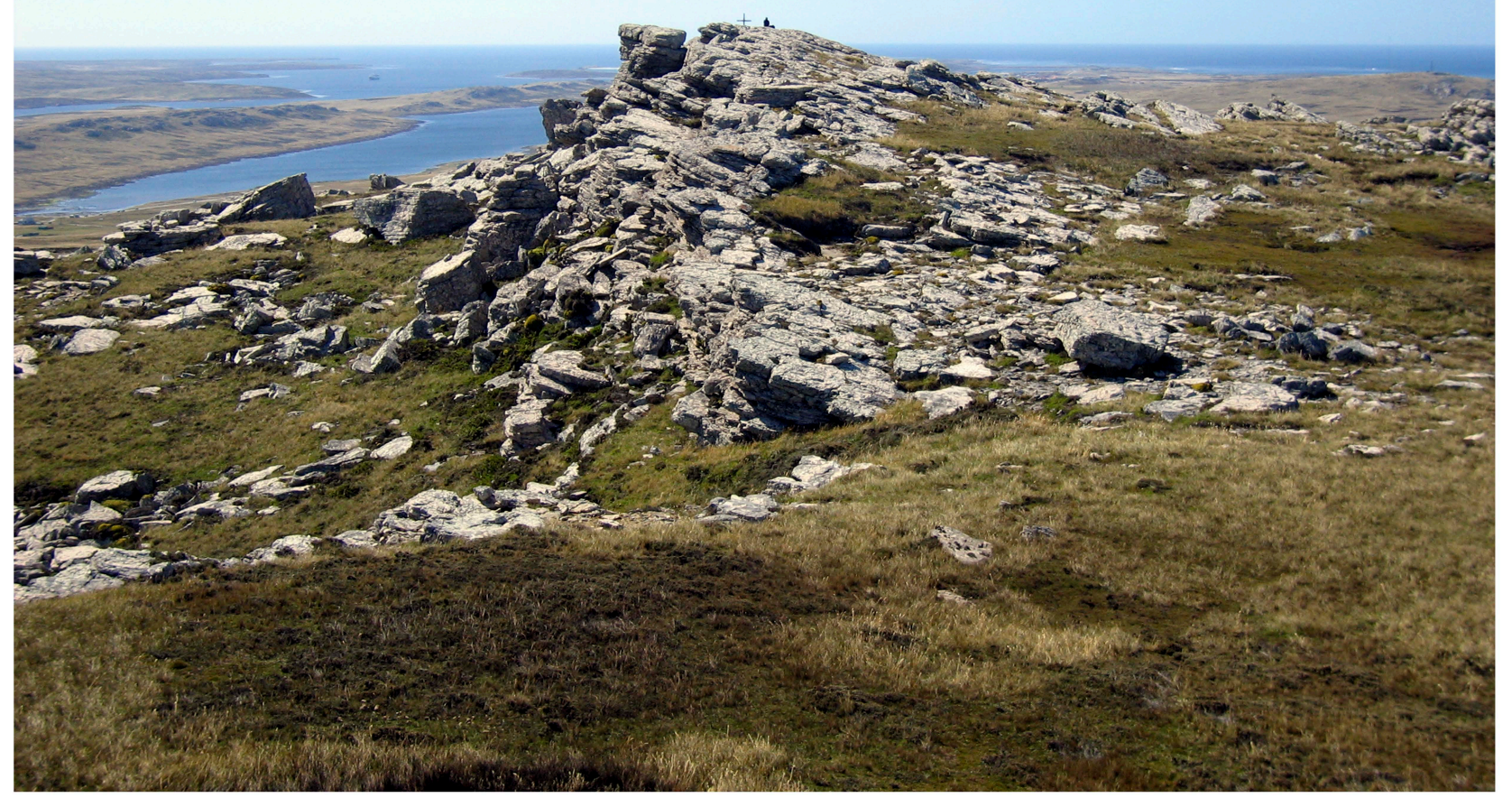

b

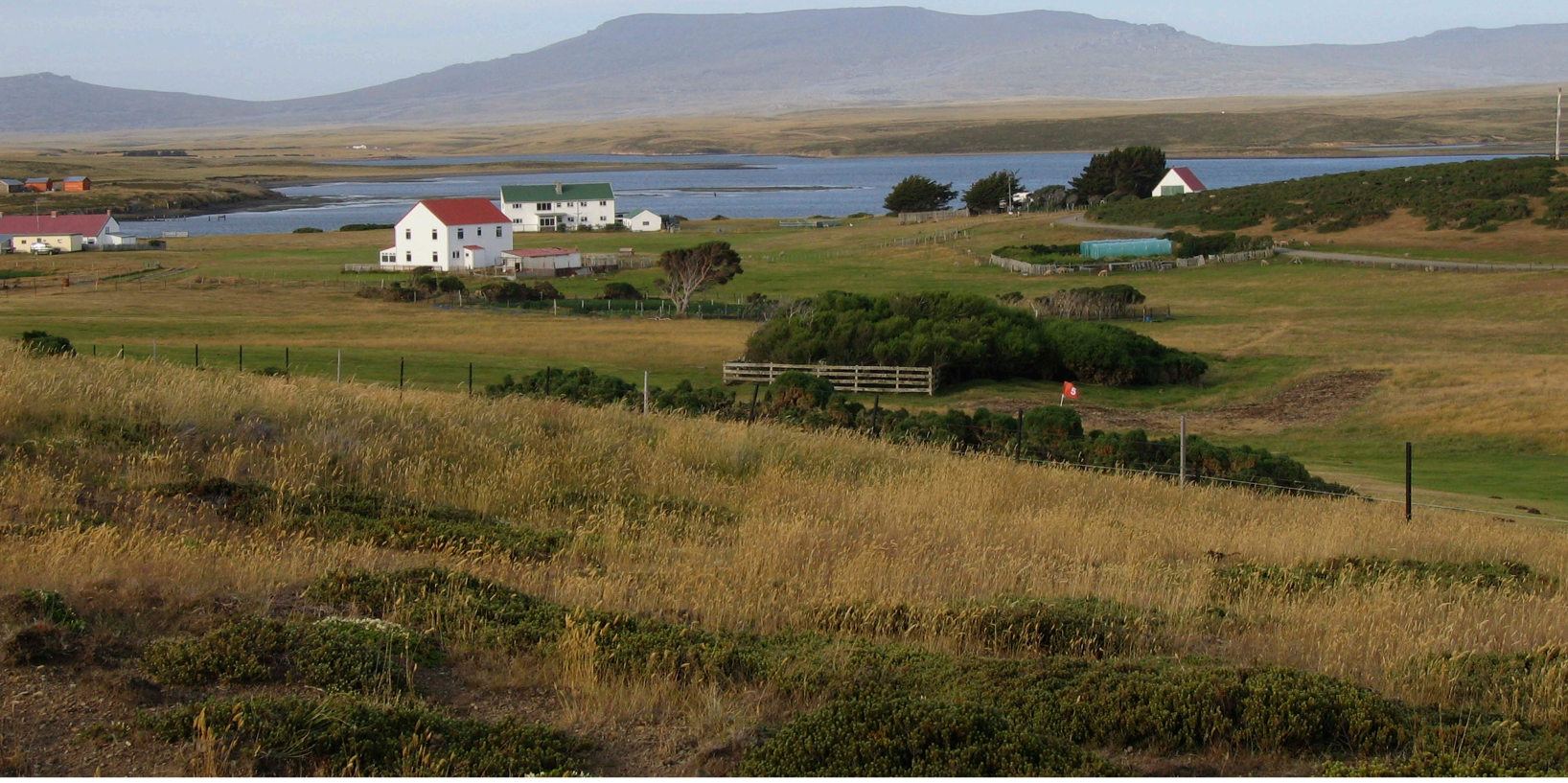



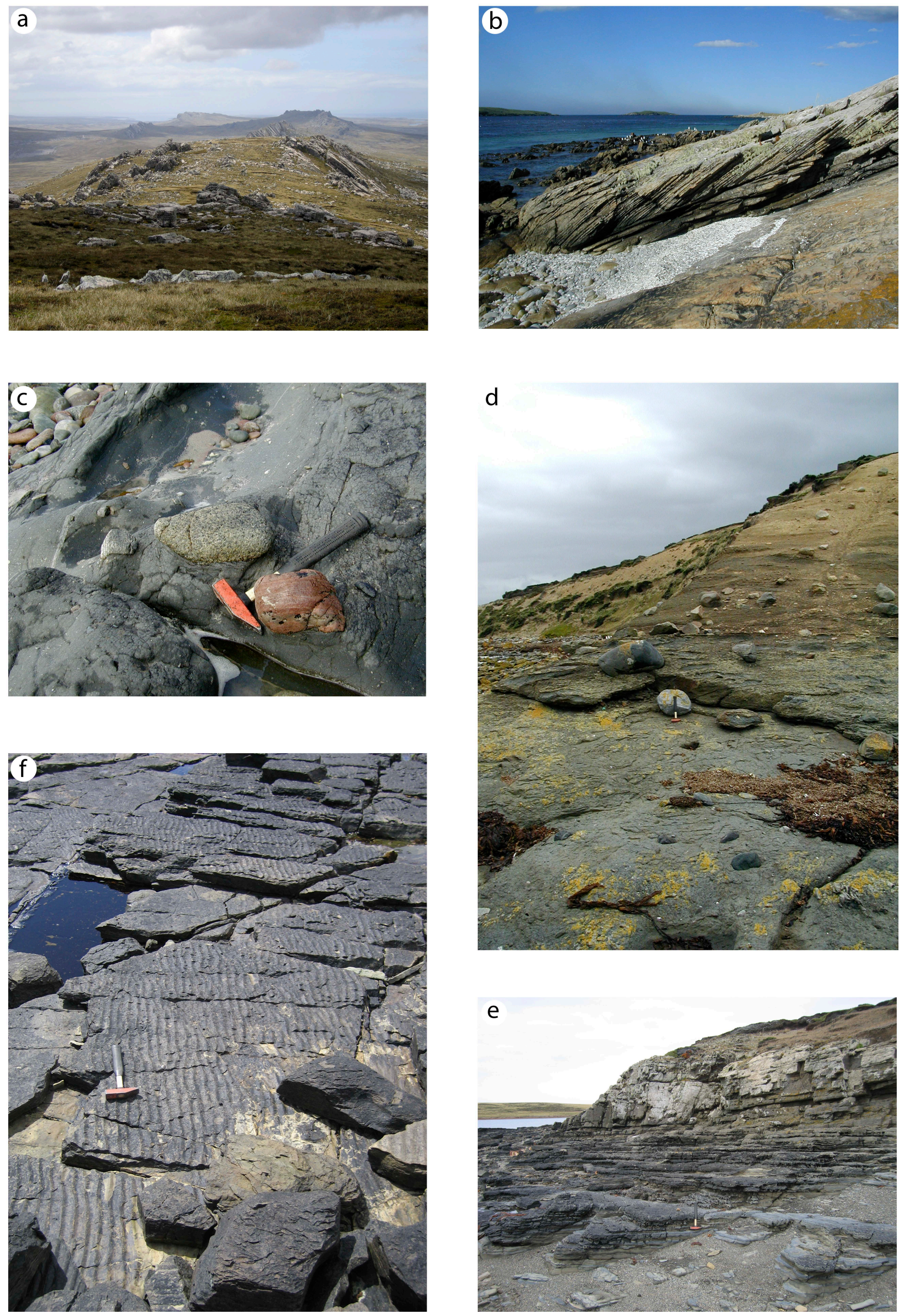
A
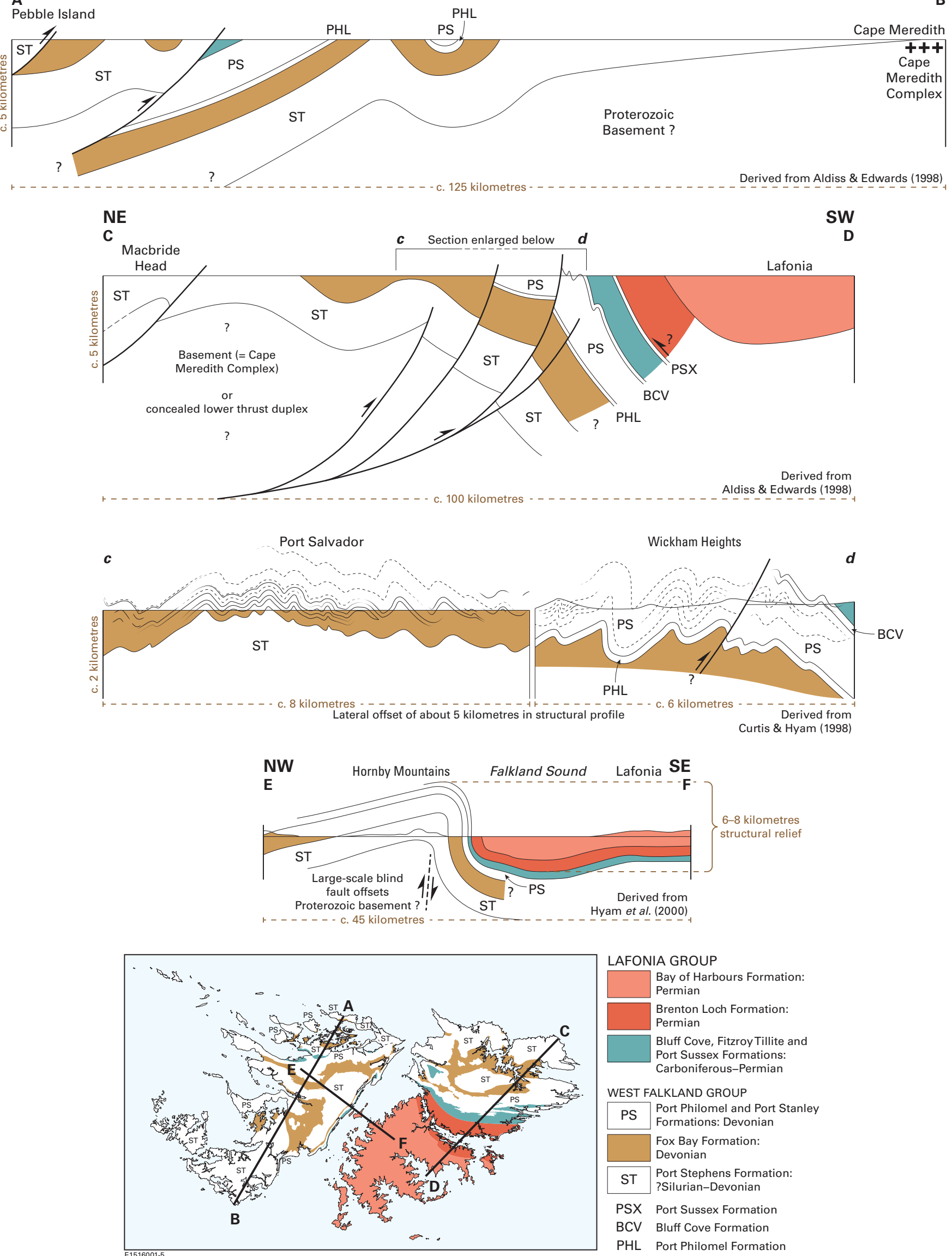

LAFONIA GROUP

Bay of Harbours Formation

Permian

Brenton Loch Formation

Permian

Bluff Cove, Fitzroy Tillite and

Port Sussex Formations:

Carboniferous-Permian

WEST FALKLAND GROUP

PS Port Philomel and Port Stanley

PS Formations: Devonian

Fox Bay Formation:

Devonian

ST Port Stephens Formation:

?Silurian-Devonian

PSX Port Sussex Formation

BCV Bluff Cove Formation

PHL Port Philomel Formation 

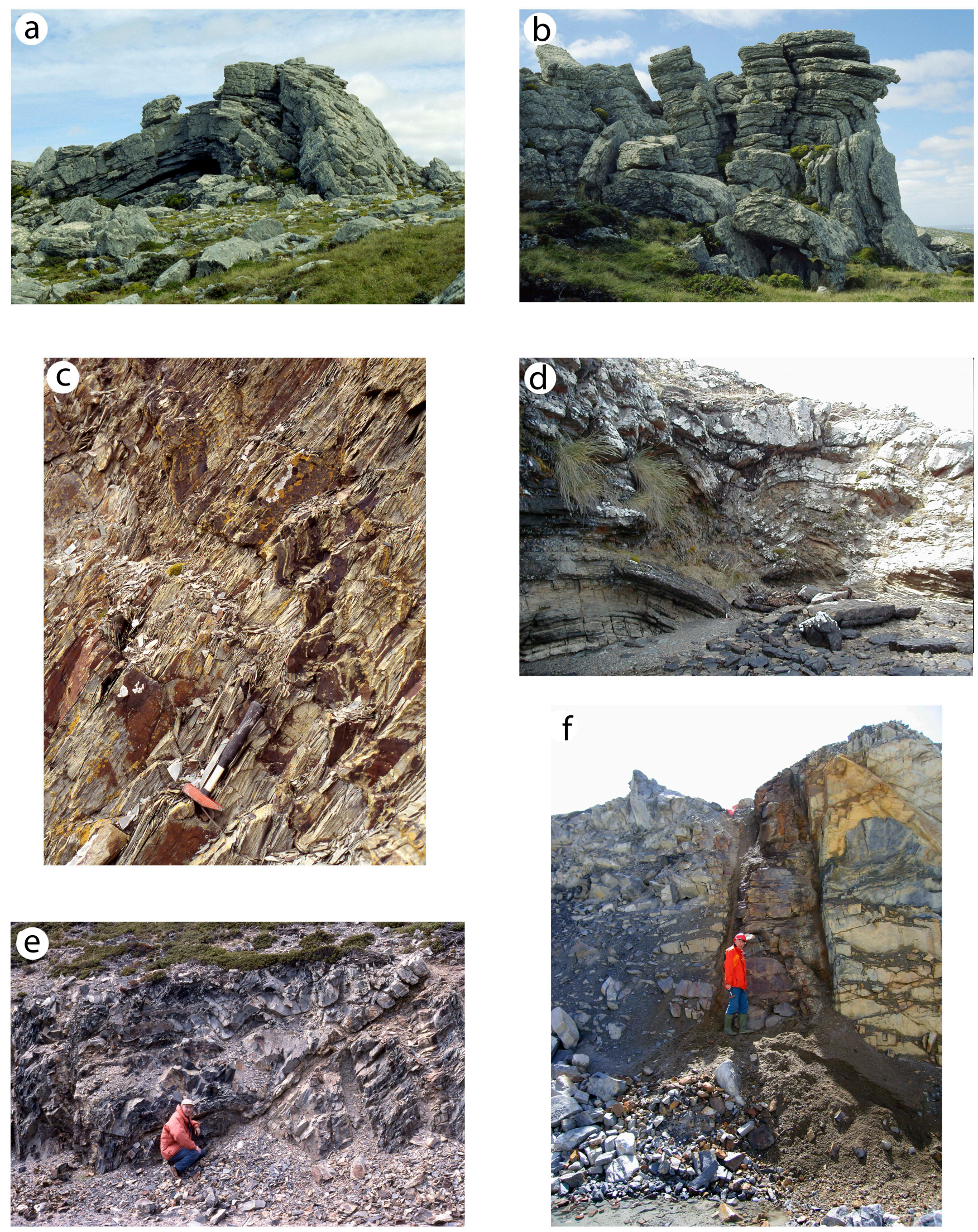


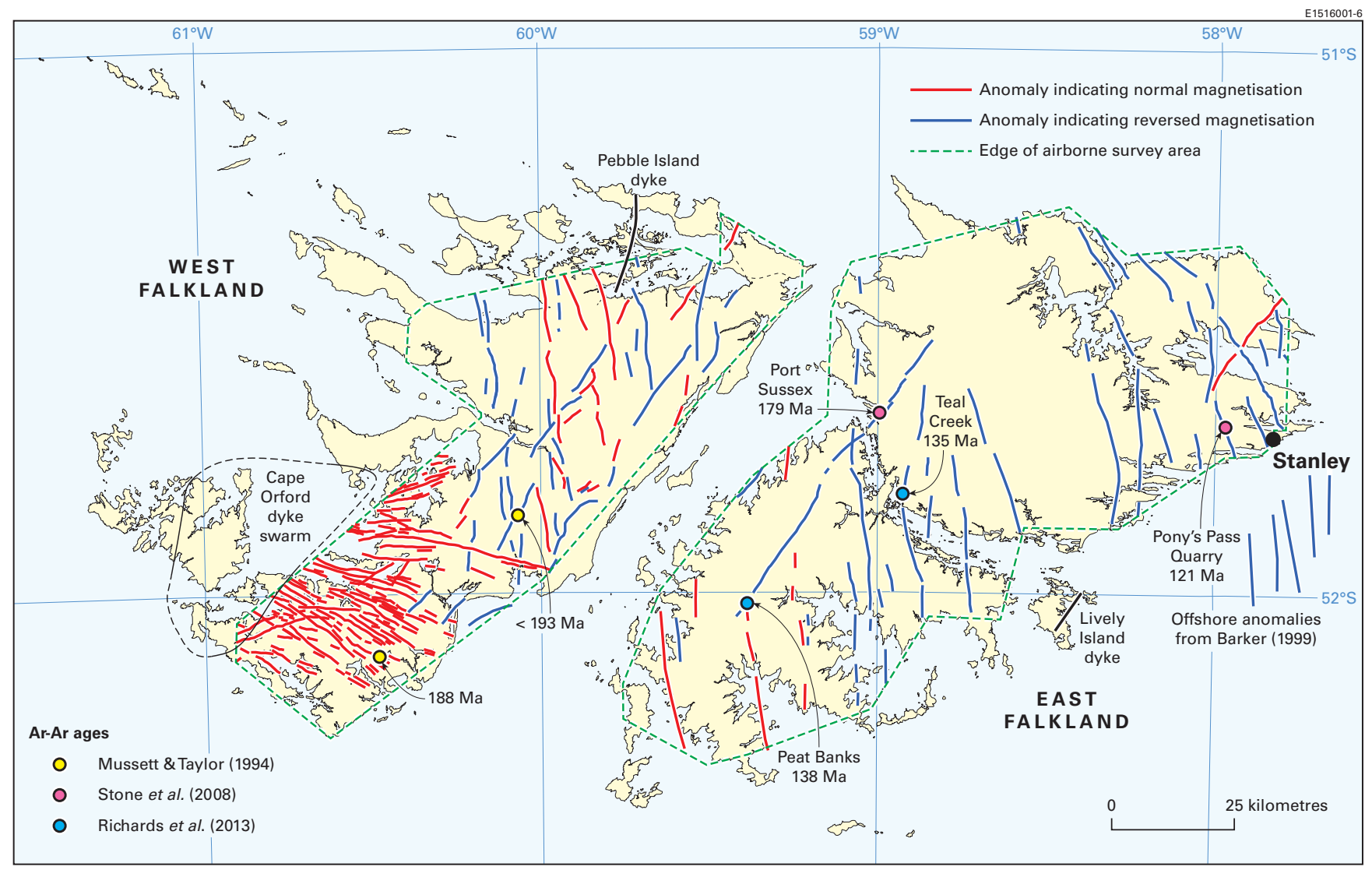



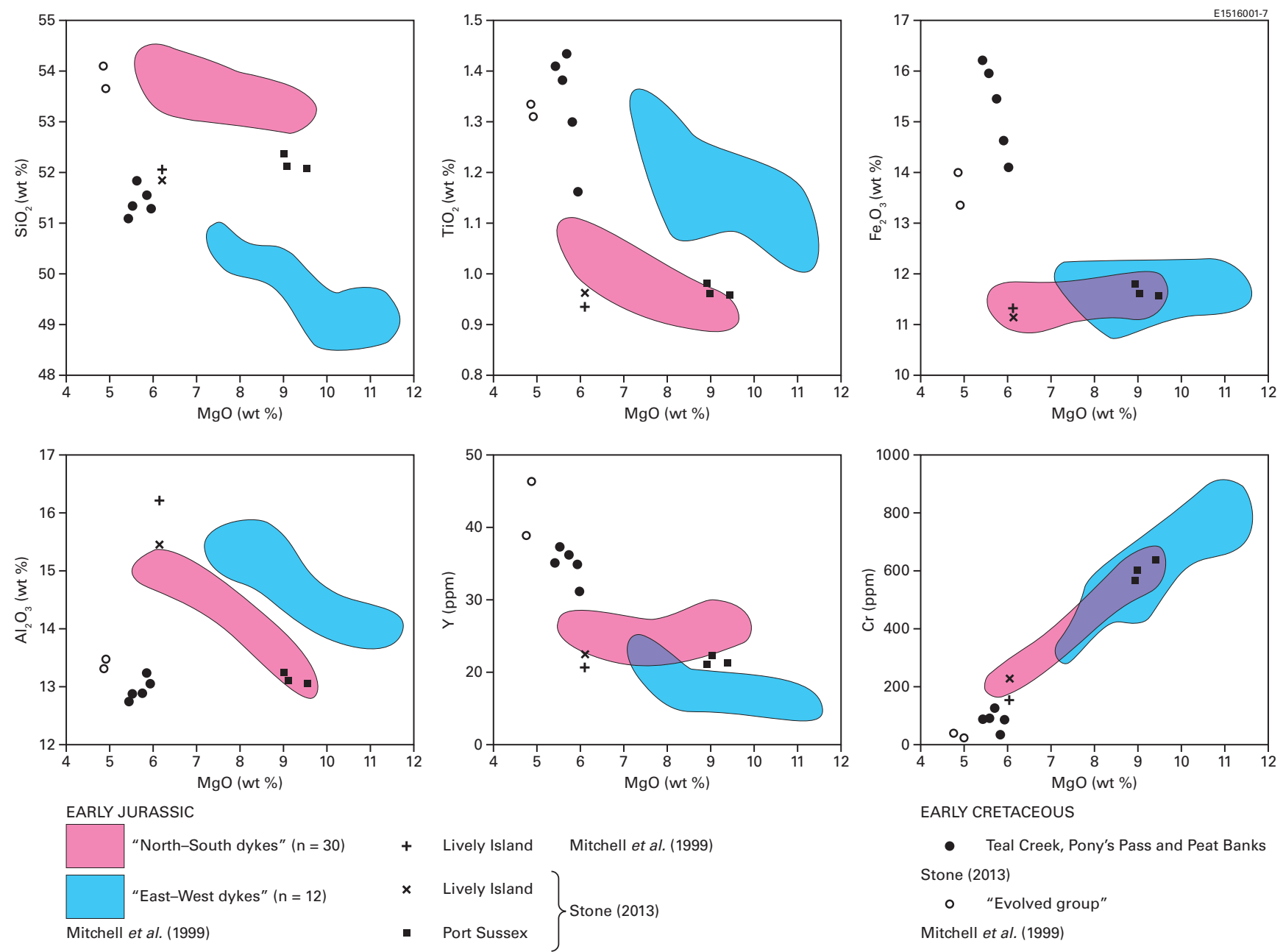

EARLY CRETACEOUS

- Teal Creek, Pony's Pass and Peat Banks Stone (2013)

- "Evolved group"

Mitchell et al. (1999) 


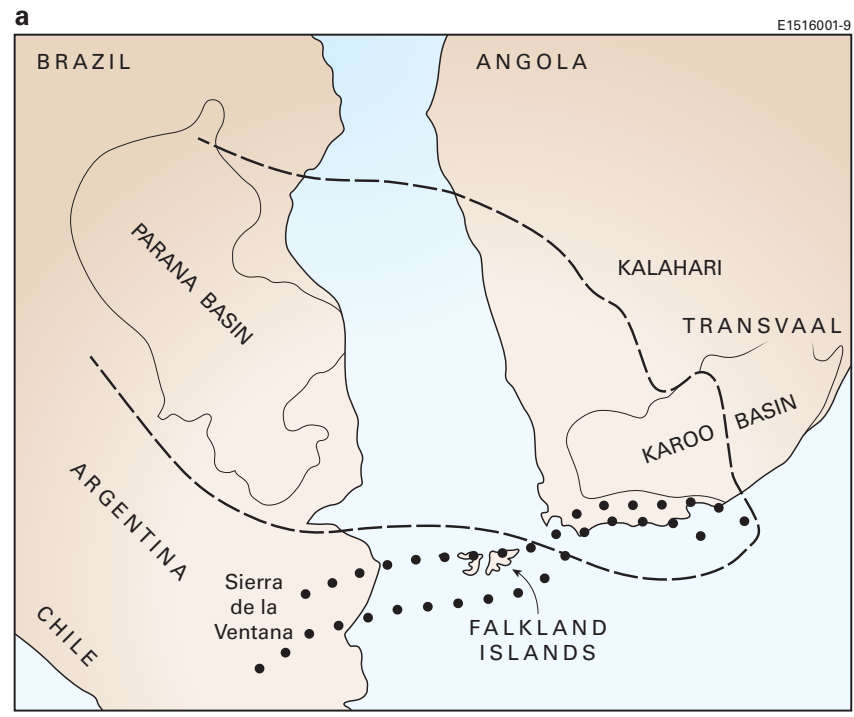

- - "Cape Foldings" - - - Limit of Mesosaurus

b

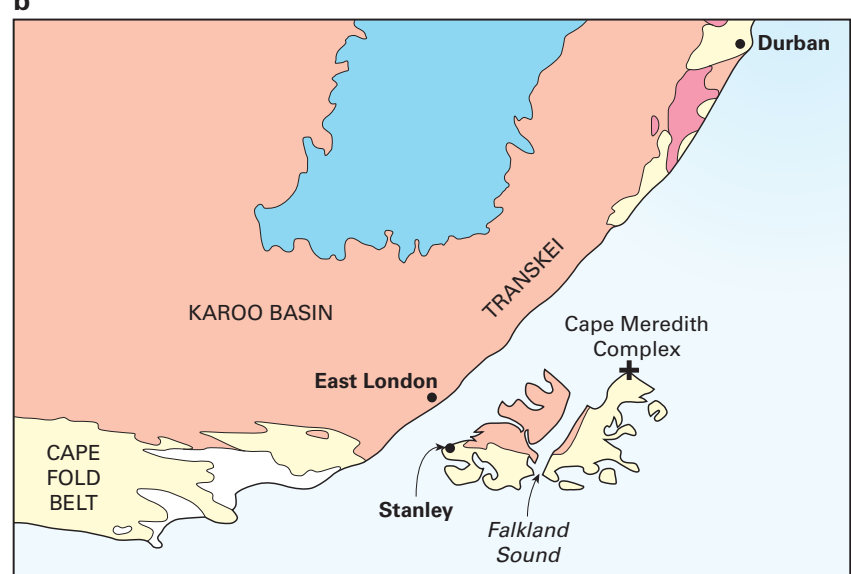

Precambrian

Permo-Triassic

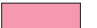
Beaufort/Ecce/Karoo/Dwyka (South Africa)
Lafonia Group (Falkland Islands)

Jurassic volcanic rocks Siluro-Devonian

Cape Supergroup (South Africa)

West Falkland Group (Falkland Islands)

Stormberg Series 


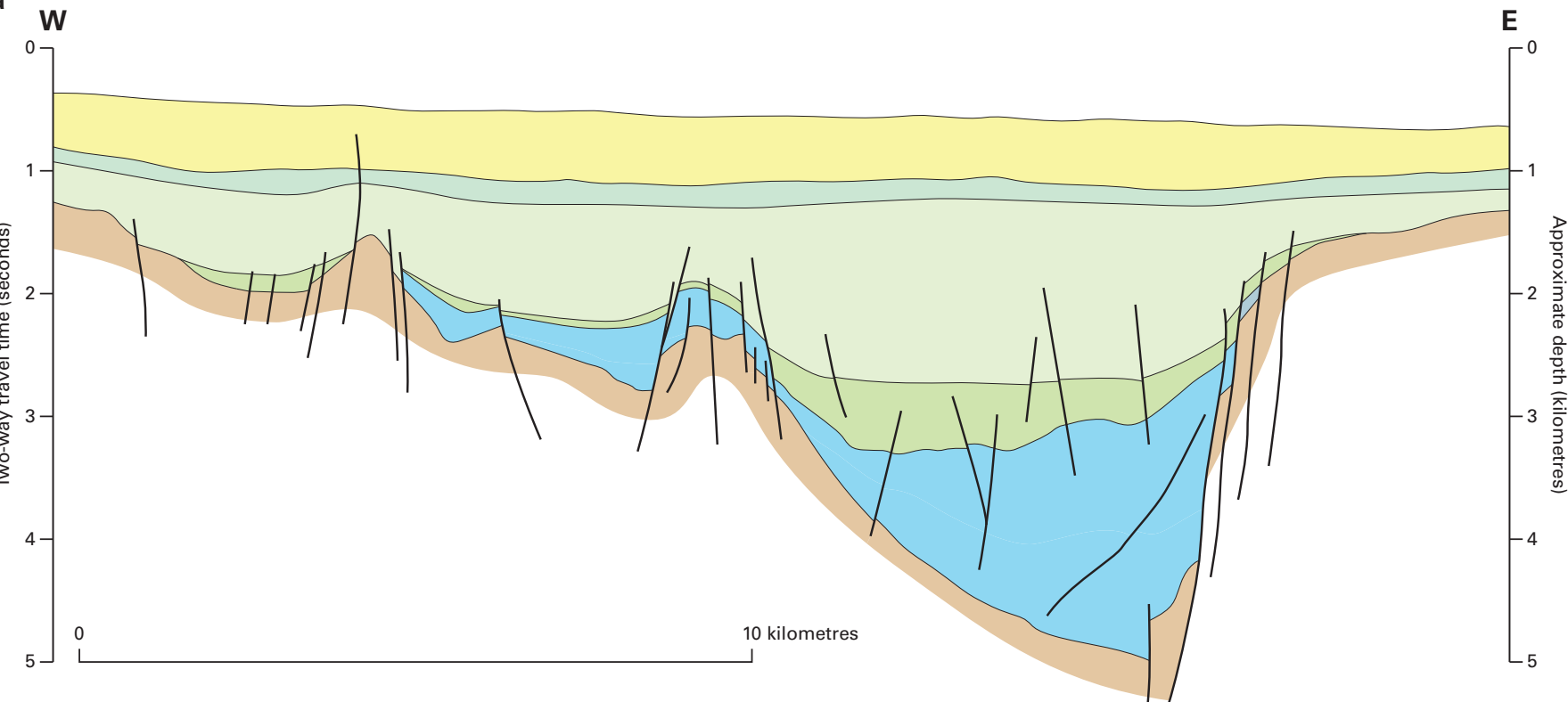

b

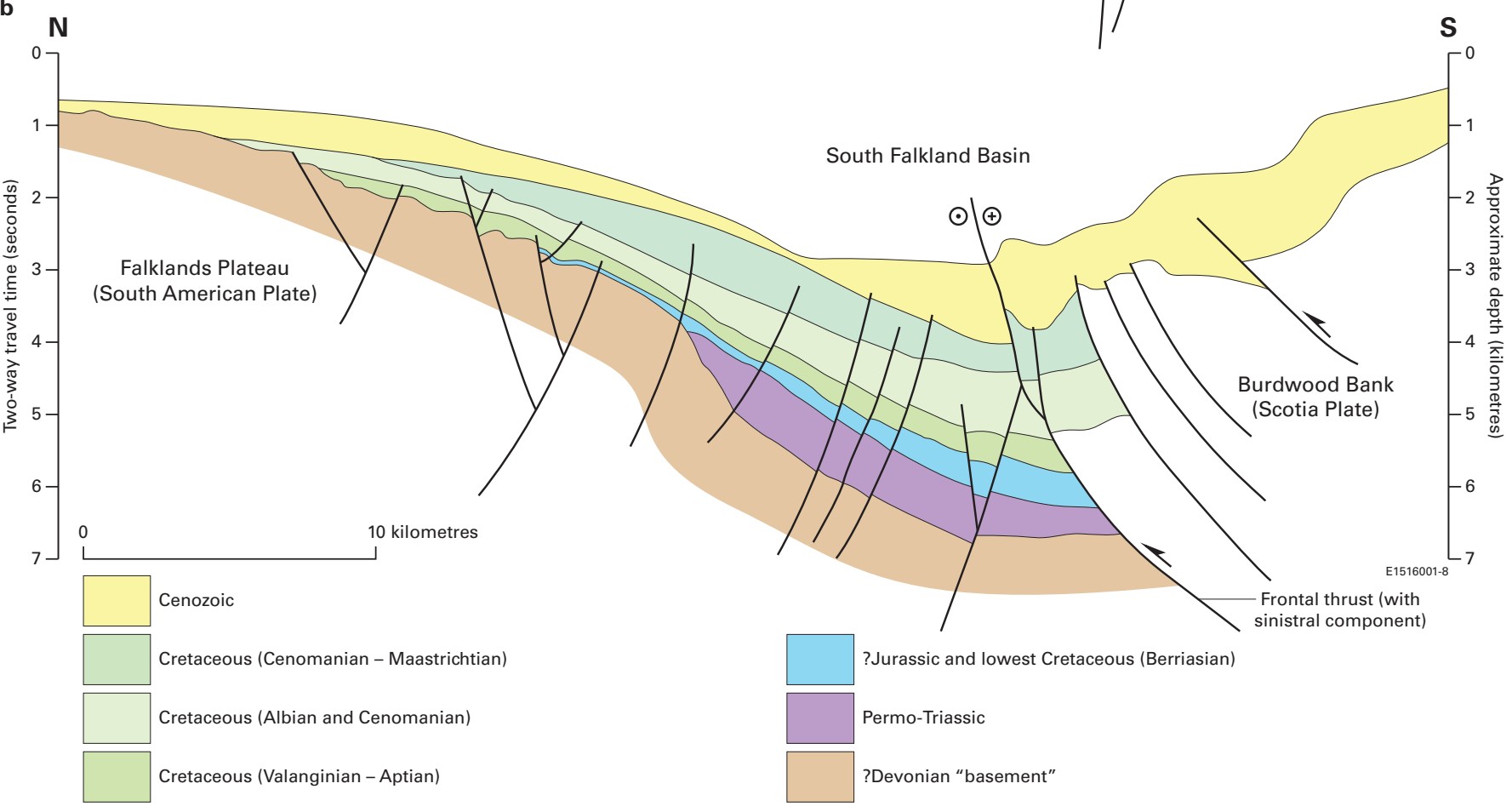




\begin{tabular}{|l|l|}
\hline Falkland Islands (Formations) & South Africa (Groups) \\
\hline & \\
\hline Bay of Harbours & Beaufort (lower part) \\
\hline Brenton Loch & Ecca (upper part) and Beaufort (lowermost part) \\
\hline Port Sussex & Ecca (lower part) \\
\hline Fitzroy Tillite & Dwyka \\
\hline Bluff Cove & No equivalent unit \\
\hline & \\
\hline Port Stanley & Witteberg \\
\hline Port Philomel & Bokkeveld (uppermost part) \\
\hline Fox Bay & Bokkeveld \\
\hline Port Stephens & Table Mountain (upper part) \\
\hline
\end{tabular}

